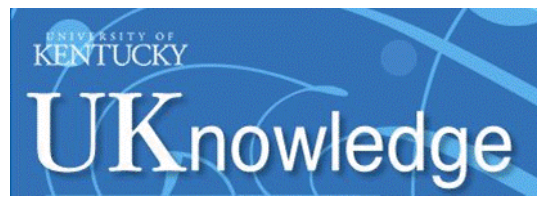

University of Kentucky

UKnowledge

Biosystems and Agricultural Engineering Faculty Publications

2018

\title{
Assessing Intra-Event Phosphorus Dynamics in Drainage Water Using Phosphate Stable Oxygen Isotopes
}

\author{
William Ford III \\ University of Kentucky, bill.ford@uky.edu \\ Mark R. Williams \\ USDA Agricultural Research Service \\ Megan B. Young \\ U.S. Geological Survey \\ Kevin W. King \\ USDA Agricultural Research Service \\ Eric Fischer \\ USDA Agricultural Research Service
}

Follow this and additional works at: https://uknowledge.uky.edu/bae_facpub

Part of the Agriculture Commons, Bioresource and Agricultural Engineering Commons, and the Hydrology Commons

Right click to open a feedback form in a new tab to let us know how this document benefits you.

\section{Repository Citation}

Ford, William III; Williams, Mark R.; Young, Megan B.; King, Kevin W.; and Fischer, Eric, "Assessing IntraEvent Phosphorus Dynamics in Drainage Water Using Phosphate Stable Oxygen Isotopes" (2018). Biosystems and Agricultural Engineering Faculty Publications. 227.

https://uknowledge.uky.edu/bae_facpub/227

This Article is brought to you for free and open access by the Biosystems and Agricultural Engineering at UKnowledge. It has been accepted for inclusion in Biosystems and Agricultural Engineering Faculty Publications by an authorized administrator of UKnowledge. For more information, please contact UKnowledge@lsv.uky.edu. 
Assessing Intra-Event Phosphorus Dynamics in Drainage Water Using Phosphate Stable Oxygen Isotopes

\section{Digital Object Identifier (DOI)}

https://doi.org/10.13031/trans.12804

Notes/Citation Information

Published in Transactions of the ASABE, v. 61, issue 4, p. 1379-1392.

The copyright holder has granted the permission for posting the article here. 


\title{
ASSESSING INTRA-EVENT PHOSPHORUS DYNAMICS IN DRAINAGE WATER USING PHOSPHATE STABLE OXYGEN ISOTOPES
}

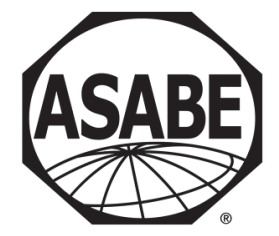

\author{
W. Ford III, M. R. Williams, M. B. Young, K. W. King, E. Fischer
}

\begin{abstract}
Quantifying fluxes and pathways of dissolved reactive phosphorus (DRP) in tile-drained landscapes has been hampered by a lack of in situ measurements that are sensitive to $P$ fate and transport processes. One potential tool to help understand these dynamics is the oxygen isotope signature of phosphate $\left(\delta^{18} O_{P O 4}\right)$; however, its potential benefits and limitations are not well understood for intra-event dynamics at the field scale. The objectives of this study were to quantify intra-event variability of $\delta^{18} \mathrm{O}_{P O 4}$ signatures in tile drainage water and assess the efficacy of $\delta^{18} \mathrm{O}_{\mathrm{PO}}$ to elucidate mechanisms and flow pathways controlling DRP transport to tile drains. We collected water samples during a summer storm event from a subsurface (tile)-drained field located in west-central Ohio and analyzed for $\delta^{18} \mathrm{O}_{P O 4}$ of DRP. Supplementary water quality measurements, hydrologic modeling, and soil temperature data were used to help understand intra-event $\delta^{18} O_{P O 4}$ dynamics. Results of the soil extraction analysis from our study site highlight that the soil water-extractable P (WEP) pool was not in equilibrium with long-term, temperature-dependent water isotope values. This result suggests that P-rich soils may, at least partially, retain their original source signature, which has significant implications for identifying hotspots of $P$ delivery in watershed-scale applications. Results of the storm event analysis highlight that equilibration of leached DRP in soil water creates a gradient between isotopic compositions of pre-event shallow subsurface sources, pre-event deep subsurface sources, and the WEP tied up in surface soils. The current study represents the first intra-event analysis of $\delta^{18} \mathrm{O}_{\mathrm{PO} 4}$ and highlights the potential for phosphate oxygen isotopes as a novel tool to improve understanding of $P$ fate and transport in artificially drained agroecosystems.
\end{abstract}

Keywords. Agriculture, Edge-of-field, Macropores, Phosphate oxygen isotopes, Tile-drainage.

$\mathrm{E}$ xcess phosphorus (P) losses from agricultural lands have been linked to harmful algal blooms in surface water bodies across the globe (Abell et al., 2012). Decades of intensive agricultural management has resulted in the accumulation of $P$ in many fields (Powers et al., 2016), most of which is found in near-surface soils (Baker et al., 2017). Throughout the Midwestern U.S. and other poorly drained landscapes, subsurface (tile) drainage is often the dominant pathway for dissolved reactive $\mathrm{P}$ (DRP) transport from agricultural fields to nearby waterways (Macrae et al., 2007; Blann et al., 2009; King et al.,

Submitted for review in February 2018 as manuscript number NRES 12804; approved for publication by the Natural Resources \& Environmental Systems Community of ASABE in May 2018.

Mention of company or trade names is for description only and does not imply endorsement by the USDA. The USDA is an equal opportunity provider and employer.

The authors are William Ford III, Assistant Professor, Department of Biosystems and Agricultural Engineering, University of Kentucky, Lexington, Kentucky; Mark R. Williams, Research Agricultural Engineer, USDA-ARS National Soil Erosion Research Laboratory, West Lafayette, Indiana; Megan B. Young, Research Hydrologist, U.S. Geological Survey, Water Resources Mission Area, Menlo Park, California; Kevin W. King, Research Leader, and Eric Fischer, Biological Science Lab Technician, USDA-ARS Soil Drainage Research Laboratory, Columbus, Ohio. Corresponding author: William Ford, 128 C.E. Barnhart Bldg., University of Kentucky, Lexington, KY 40546; phone: 859-218-4368; e-mail: bill.ford@uky.edu. 2015a, 2015b; Jarvie et al., 2017). While it is widely recognized that tile drains increase the hydrologic connectivity between fields and adjacent surface waters, the mechanisms controlling DRP fate and transport between surface soils and tile drains are poorly understood. Understanding these DRP dynamics is critical for development and implementation of field-scale management strategies to reduce DRP loadings.

Studies investigating the partitioning of flow pathways via stable water isotope tracing and numerical models have found that between $10 \%$ and $90 \%$ of tile discharge during storm events was comprised of event water (Vidon and Caudra, 2010; Granger et al., 2010; Kennedy et al., 2012; Klaus et al., 2013) On an annual basis, the significance of macropore flow is evidenced by recent results from a modeling study performed in Ohio, suggesting that $48 \%$ of tile discharge originates from macropore pathways (Ford et al., 2017). Two prominent flow pathways, saturated macropore flow and unsaturated macropore flow, have been hypothesized to account for this rapid transport of event water through the subsurface during storm events. For saturated macropore flow, the soil moisture content exceeds the water holding capacity of the soil matrix, and rapid flow paths such as earthworm burrows, fingered paths, and root channels are activated (Klaus et al., 2013). In contrast, under dry antecedent conditions, desiccation cracks in shrink-swell soils can develop. When soil infiltration capacity is exceeded at the 
onset of an event or when ponding occurs, these cracks can serve to transport water and contaminants rapidly to tile drains (Nimmo et al., 2012).

Increases in DRP concentration in tile flow during storm events are likely the result of near-surface $\mathrm{P}$ sources being transported to tile drains by preferential flow pathways. However, few studies have explicitly focused on partitioning the pathways of DRP delivery. Recent work in tile-drained fields in Ohio has used both field observations between DRP concentration and water isotope tracers (Williams et al., 2016a) and numerical modeling of saturated and unsaturated flow (Ford et al., 2017) to link DRP with specific flow pathways. While both studies provided new insights into DRP dynamics, these studies and others have acknowledged the confounding influence of matrix-macropore interactions on the fate of DRP whereby flow may enter or exit macropores at various depths in the soil profile. Methods for directly tracing the source and transformation of $\mathrm{P}$ will be vital to improve understanding of DRP fate and transport during storm events in tile-drained fields.

Using the stable oxygen $(\mathrm{O})$ isotope ratio of ${ }^{18} \mathrm{O} /{ }^{16} \mathrm{O}$ in phosphate $\left(\delta^{18} \mathrm{O}_{\mathrm{PO} 4}\right)$ is an emerging approach that has been employed to study microbial $\mathrm{P}$ cycling and $\mathrm{P}$ source apportionment in both inland and coastal surface water bodies (Elsbury et al., 2009; Young et al., 2009; McLaughlin et al., 2013; Granger et al., 2017; Tonderski et al., 2017) and soils and sediments (Jaisi et al., 2011; Tamburini et al., 2012, 2014; Joshi et al., 2016; Pistocchi et al., 2017). Previous studies employing $\delta^{18} \mathrm{O}_{\mathrm{PO} 4}$ have largely been conducted either during a single sampling campaign (e.g., grab samples from several locations along a stream reach in addition to potential end-member sources of P) or seasonally. Despite the dynamic nature of DRP transport during storm events, there are currently no studies that have examined patterns of $\delta^{18} \mathrm{O}_{\mathrm{PO} 4}$ within an event. The objectives of the current study were to (1) quantify intra-event variability of $\delta^{18} \mathrm{O}_{\mathrm{PO} 4}$ signatures in tile drainage water during a large summer storm event and (2) assess the efficacy of $\delta^{18} \mathrm{O}_{\mathrm{PO} 4}$ in combination with modeling and supplementary soil and water quality data to elucidate potential mechanisms and flow pathways controlling DRP transport to tile drains.

\section{MethODS}

\section{STUDY SITE}

A privately owned tile-drained field located in Mercer County, Ohio, was monitored for a storm event in late June 2015 (fig. 1). The field site is part of a broader USDA-ARS edge-of-field research program established to quantify the impact of conservation practices on nutrient fluxes in surface and subsurface pathways (Williams et al., 2016b). The field had a surface and subsurface drainage area of 3.7 ha and was characterized by low hillslope gradients ( $1 \%$ to $3 \%$ ), tile laterals approximately $1 \mathrm{~m}$ deep, and somewhat poorly drained clay-loam soils (Blount and Glynwood soil series). The study site receives an average of $973 \mathrm{~mm}$ of precipitation, based on edge-of-field monitoring over the past five years. Surface runoff and tile drainage accounts for $16 \%$ and $14 \%$, respectively, of annual precipitation. The monitored storm event for this study occurred on June 26-28, 2015. A total of $99.4 \mathrm{~mm}$ of precipitation fell over the three-day period, generating $9.6 \mathrm{~mm}$ of tile flow and $30.0 \mathrm{~mm}$ of surface runoff.

Historically, the field was managed by the same producer under a corn-soybean rotation. In 2015, corn was planted on May 8, and surface application of urea and ammonium nitrate at a rate of $281 \mathrm{~L} \mathrm{ha}^{-1}\left(119.5 \mathrm{~kg} \mathrm{ha}^{-1}\right.$ of N) was completed on June 12, two weeks prior to the monitored storm event. Prior to 2005, poultry litter was regularly applied to the field to meet crop $\mathrm{N}$ demand, which resulted in elevated soil $\mathrm{P}$ concentration. No $\mathrm{P}$ fertilizer has been applied to the field since 2005, and the average Mehlich-3 P concentration in the upper $20 \mathrm{~cm}$ was $312 \mathrm{ppm}$, based on soil samples collected in the fall of 2015 (Duncan et al., 2017). These soil test $\mathrm{P}$ concentrations are considered high by agronomic standards, exceeding recommendations for no additional Pbased fertilizer applications by an order of magnitude (Vi-
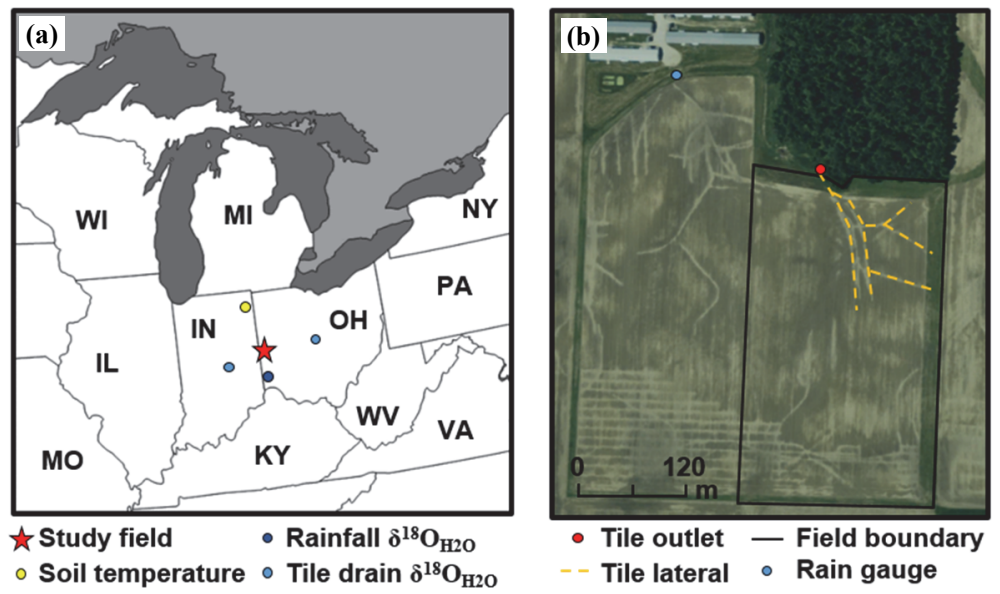

Figure 1. (a) Map of the Great Lakes region showing the location of the study field as well as the supplemental soil temperature and stable water isotope data, and (b) aerial photo of the study field showing the location of tile laterals and tile outlet monitoring station. Soil temperature data were collected in DeKalb County, Indiana, from two fields with the same soil series between 2006 and 2016 . Stable water isotope data were collected from tile drainage water in Hancock County, Indiana (Vidon and Cuadra, 2010) and Delaware County, Ohio (Williams et al., 2016a). The rainfall and river stable water isotope calibration site used by Kendall and Coplen (2001) and Dutton et al. (2005) near Oxford, Ohio, is also shown. 
tosh et al., 1995). As a result, large annual losses of DRP in surface runoff ( 0.6 to $\left.2.4 \mathrm{~kg} \mathrm{ha}^{-1}\right)$ and tile drainage $(0.7$ to $2.7 \mathrm{~kg} \mathrm{ha}^{-1}$ ) have been observed from this field (Pease et al., 2018).

\section{SAMPle Collection AND ANALYSIS Soil Samples}

Three soil cores ( $1 \mathrm{~m}$ deep) were collected in May 2015 from six locations in the study field (18 total soil cores) using a soil probe (Giddings Machine Co., Windsor, Colo.) to characterize the distribution of $\mathrm{P}$ throughout the soil profile. Cores were partitioned into six depth increments $(0-5,5-20$, 20-35, 35-50, 50-65, and 65-80 cm). Water-extractable $\mathrm{P}$ (WEP) concentrations in soil samples were determined following Self-Davis et al. (2000). Briefly, soil samples were dried $\left(60^{\circ} \mathrm{C}\right.$ for $\left.48 \mathrm{~h}\right)$, sieved $(2 \mathrm{~mm})$, and a $1: 10$ soil to water ratio was shaken for $1 \mathrm{~h}$ on a reciprocating shaker. The suspension was then filtered $(0.45 \mu \mathrm{m})$ and immediately analyzed with a discrete analyzer (SEAL Analytical Inc., Mequon, Wisc.) for molybdate reactive $\mathrm{P}$. Water-extractable $\mathrm{P}$ was chosen because it is a direct measure of soil solution $\mathrm{P}$ concentration and previous studies have found strong correlations between soil WEP and runoff DRP concentration (Pote et al., 1996).

\section{Water Samples}

The field tile drain was instrumented with a compound weir insert (Thel-Mar LLC, Brevard, N.C.) and Isco 4230 bubbler flowmeter (Teledyne Isco, Lincoln, Neb.) to record water depth at 10 min intervals. Water samples $(900 \mathrm{~mL})$ were collected using Isco 6712 portable water samplers (with PVC vinyl tubing). During a large summer storm event (June 26-28), water samples were collected hourly. In total, 56 water samples were collected. Samples were retrieved from the field during and immediately following the storm event, filtered $(0.45 \mu \mathrm{m})$, and refrigerated $\left(4^{\circ} \mathrm{C}\right)$. Based on previously collected nutrient data from the study field, water samples were composited to ensure enough volume for subsequent phosphate oxygen isotope analysis, which resulted in an average sample collection interval of $2.5 \mathrm{~h}$ during the event and 23 composited samples. Concentrations of $\mathrm{PO}_{4}-\mathrm{P}$, $\mathrm{NO}_{3}-\mathrm{N}$, and $\mathrm{NH}_{4}-\mathrm{N}$ were determined colorimetrically (USEPA, 1983) by flow injection analysis using a QuikChem 8000 FIA automated ion analyzer (Lachat Instruments, Loveland, Colo.).

\section{Phosphate OXygen Isotope AnAlysis Laboratory Preparation and A nalysis}

Silver phosphate was precipitated from soil WEP and tile water samples according to the methods of McLaughlin et al. (2004). Regarding laboratory preparation of tile-drain and WEP samples, two large teaspoons of $\mathrm{MgCl}-6 \mathrm{H}_{2} \mathrm{O}$ and $150 \mathrm{~mL}$ of $1 \mathrm{M} \mathrm{NaOH}$ were added to the samples, which were then placed in the refrigerator overnight. The following day, the samples were siphoned and centrifuged at $3500 \mathrm{rpm}$ in $250 \mathrm{~mL}$ bottles. Nitric acid $(10 \mathrm{M})$ was used to clean the original sample container, and it was added to the current sample container along with $5 \mathrm{~mL}$ of concentrated acetic acid and $10 \mathrm{~mL}$ of $1 \mathrm{M}$ potassium acetate. A cerium nitrate solution was added to the samples to precipitate cerium phosphate, and the samples sat overnight. The $250 \mathrm{~mL}$ solution was consolidated to $50 \mathrm{~mL}$ by centrifuging and decanting of the supernatant. The cerium phosphate solution was then repeatedly rinsed with $0.5 \mathrm{M}$ potassium acetate and centrifuged to ensure removal of chloride ions. The rinsed cerium phosphate was dissolved with $1 \mathrm{M}$ nitric acid, and $4.5 \mathrm{~mL}$ of conditioned cation exchange resin (Bio-Rad AG $50 \mathrm{~W}-\mathrm{X} 8$ ) was added to remove cerium ions. The sample was placed on a shaker table overnight, and then water was separated from the resin using Kimball glass columns. We added $1 \mathrm{~mL}$ of $2 \mathrm{M}$ ammonium nitrate, reduced the $\mathrm{pH}$ to 7 , and dissolved $0.5 \mathrm{~g}$ of silver nitrate to precipitate the silver phosphate solution. The sample was vacuum-filtered and dried in a Petri dish at $50^{\circ} \mathrm{C}$ overnight.

Upon initial analysis, we found interference from dissolved organic matter for the water samples; therefore, hydrogen peroxide was added to the precipitated silver phosphate to remove organic matter, and the samples were reanalyzed (Zohar et al., 2010b). While it is possible to introduce new inorganic $\mathrm{P}$ during hydrogen peroxide rinses, it is unlikely to have impacted our $\delta^{18} \mathrm{O}_{\mathrm{PO} 4}$ measurements because no additional free silver was available for formation of additional precipitate at that stage (Tamburini et al., 2010). For both soil extract and water samples, the final precipitated silver phosphate was weighed $(0.3$ to $0.4 \mathrm{mg})$ into silver capsules, and approximately $1 \mathrm{mg}$ of nickelized carbon $(\mathrm{NiC})$ was added to each capsule. The $\delta^{18} \mathrm{O}$ value of the silver phosphate was measured using thermal decomposition at $1270^{\circ} \mathrm{C}$ on a Eurovector elemental analyzer coupled to an IsoPrime continuous-flow isotope ratio mass spectrometer (CFIRMS) at the U.S. Geological Survey Stable Isotope Laboratory (Menlo Park, Cal.). Two internal silver phosphate standards, MR-3 (+10.9\%o) and MR-4 (+20.2\%o), were used for calibration and analyzed at three different size ranges (spanning the range of sample weights) at the beginning and end of each run and after each batch of $\sim 10$ samples. Blanks consisting of empty silver capsules and silver capsules containing only $\mathrm{NiC}(\sim 1 \mathrm{mg})$ were included with each analytical run, and no oxygen contamination was detected. Analytical precision averaged $0.4 \%$ for $\delta^{18} \mathrm{O}$ based on replicate analyses of the silver phosphate standards. The $\delta^{18} \mathrm{O}$ isotopic values are reported using standard delta notation relative to $\mathrm{Vi}$ enna Standard Mean Ocean Water (VSMOW).

\section{Expected $\delta^{18} \mathrm{O}_{P 04}$ Equilibrium Calculations}

Phosphorus cycling in the soil is well recognized to alter the oxygen isotopic signature of $\mathrm{P}$ pools and can be predicted using a temperature-dependent equilibrium fractionation equation (Tamburini et al., 2014). The $\delta^{18} \mathrm{O}_{\mathrm{PO} 4}$ values expected for temperature-dependent isotopic equilibrium with water $\delta^{18} \mathrm{O}_{\mathrm{H} 2 \mathrm{O}}$ signatures were calculated using the following equation defined by Chang and Blake (2015):

$$
\delta^{18} \mathrm{O}_{\mathrm{PO} 4}=14.43\left(\frac{1000}{T+273.15}\right)-26.54+\delta^{18} \mathrm{O}_{\mathrm{H} 2 \mathrm{O}}
$$

where $T$ is water temperature $\left({ }^{\circ} \mathrm{C}\right)$, and $\delta^{18} \mathrm{O}_{\mathrm{H} 2 \mathrm{O}}$ is the oxygen isotope signature of water (\%o). The equation derived by Chang and Blake (2015) was based on a rigorous and controlled laboratory calibration of the temperature-dependence 
of equilibrium phosphate and water, catalyzed by inorganic pyrophosphatase over a range of typical environmental temperatures. While soil temperatures and $\delta^{18} \mathrm{O}_{\mathrm{H} 2 \mathrm{O}}$ measurements were not explicitly measured at the field site during the specified event, supplementary data and literature values obtained from tile-drained fields in the region were used to provide estimates for both (fig. 1). Air temperature, soil type, and water content are governing parameters regulating soil temperature (Williams et al., 2012). In the absence of soil temperature data at our study site, we were able to apply data from two fields approximately $120 \mathrm{~km}$ north of our field sampling site that had the same soil series (Blount and Glynwood), average annual precipitation (900 to $1000 \mathrm{~mm}$ ), and average annual air temperature $\left(10^{\circ} \mathrm{C}\right.$ to $\left.11^{\circ} \mathrm{C}\right)$ as our event monitoring site (fig. 1). During May and June 2015, average air temperature at the study site was $19.4^{\circ} \mathrm{C}$, compared to $18.6^{\circ} \mathrm{C}$ at the field site where soil temperature data were obtained. Soil temperature data were collected at 5, 20, 40, and $60 \mathrm{~cm}$ depths from 2006-2016 using HydraProbe soil sensors (Steven Water Monitoring Systems, Inc., Portland, Ore.). To calculate equilibrium $\delta^{18} \mathrm{O}_{\mathrm{PO} 4}$ values, monthly average soil temperature values for the month of June $( \pm 1$ standard deviation) at each depth were used. Regarding water isotope values, a broad range of literature-derived values for drainage waters in the region was used, which ranged from $-10 \%$ to 6\%o (Kendall and Coplen 2001). This conservative range was corroborated by recent measurements of pre-event water from tile drains in May-June of nearby tile-drained fields ranging from $-8 \%$ to $-6.63 \%$ (Vidon and Cuadra, 2010; Williams et al., 2016a).

\section{MODELING SOIL MOISTURE VARIABILITY WITH WALRUS}

Within-event variability of soil moisture has been shown to be a key factor controlling DRP transport and the susceptibility of the soil profile to macropore flow (Ford et al., 2017). In the absence of soil moisture measurements, the Wageningen Lowland Runoff Simulator (WALRUS) model was applied, calibrated, and validated for the study field (Brauer et al., 2014). The WALRUS model was selected because it is (1) broadly applicable to low-gradient shallow water table systems with surface runoff and quick return flow through overland and macropore pathways, (2) parsimonious, requiring calibration of only four parameters, and (3) capable of simulating flow partitioning at a high resolution (minutes to hours) as opposed to the more complex models that either are highly parameterized or simulate at a crude (daily to monthly) timestep. The WALRUS model continuously accounts for dynamics and interactions between five water reservoirs including land surface, quickflow, vadose zone, groundwater, and surface water. It also accounts for internal (capillary rise, infiltration, overland flow, surface-groundwater exchange) and external (evapotranspiration, surface water extraction, downstream transport) fluxes in response to a storm event. The wetness index $(W)$ is a dynamically calculated parameter, scaling between 0 and 1 , that reflects the susceptibility of precipitation to be partitioned to preferential quickflow pathways. The wetness index is simulated as:

$$
W=\cos \left(\frac{\max \left(\min \left(d_{v}, c_{w}\right), 0\right) \pi}{c_{w}}\right) \frac{1}{2}+\frac{1}{2}
$$

where $d_{v}$ is the vadose zone moisture storage deficit (mm), and $c_{w}$ is the wetness index parameter $(\mathrm{mm})$ and is calibrated based on comparison with measured data.

Previously published model forcing and evaluation data were used for the case study model application (King et al., 2016). Model forcing data included precipitation and evapotranspiration. Precipitation was measured at the field site using an Isco 674 tipping-bucket rain gauge that was corrected using a standard rain gauge (NovaLynx 260-2510). Evapotranspiration was calculated using the Penman-Monteith equation for a hypothetical short grass reference crop that was corrected for maize as a function of growth stage (Allen et al., 1998; Huffman et al., 2012).

The model was parameterized based on site characteristics and broad ranges that are default values of the model. Initializing model parameters included depth of the drainage system $\left(C_{D}\right)$, fraction of the land surface covered by water $\left(a_{s}\right)$, and initial depth of the groundwater table $\left(d_{G o}\right)$. Because the system is under free drainage, we set both $d_{G o}$ and $C_{D}$ to the depth of the tile drains $(1 \mathrm{~m})$ and set $a_{s}$ to its minimum value because our field site represented the entirety of the drainage areas. We parameterized soil properties to have characteristics of sandy-clay soils. The soil series at the study site was found to be composed of Glynwood and Blount series (NRCS web soil survey; https://websoilsurvey.sc.egov.usda.gov), which are classified as clay-loam soils. Because the soil parameter values from the BrooksCorey relationship for sandy-clay soils fall well within one standard deviation of the clay-loam series, we found its use justifiable and found this soil series to provide better results in evaluation. Parameters used to calibrate relaxation of the vadose zone, surface water runoff, wetness index, and peak runoff were calibrated within the broad default values of the model because the model was developed for a landscape comparable to our application (Brauer et al., 2014).

Model calibration was completed for the 2015 growing season (May to October) comparing simulated total runoff to observed surface and tile flow at the edge-of-field. The Nash-Sutcliffe efficiency (NSE) was used as the calibration statistic given its ubiquitous use in hydrologic and water quality models (Brauer et al., 2014). NSE was calculated for daily and hourly timesteps. Optimum model calibration was found using the hydroPSO particle swarm optimization technique (Zambrano-Bigarini and Rojas, 2013). To validate the model, we assessed both the NSE statistic and the long-term stability of the groundwater table over the entire 2015 calendar year.

\section{EXPLORATORY DATA ANALYSIS}

We were particularly interested in the applicability of the $\delta^{18} \mathrm{O}_{\mathrm{PO} 4}$ signatures for improving understanding of intraevent variability and flow pathways of DRP in tile-drained fields. Therefore, we performed an exploratory analysis in which we discretized the monitored storm event into five zones of the storm hydrograph: (1) baseflow, (2) initial wetting of the soil matrix on the rising limb of the hydrograph, 
(3) peak rainfall and flow, (4) falling limb of the hydrograph, and (5) post-event baseflow. We then compared isotope signatures during phases of the event with soil moisture variability, WEP values, soil water extract $\mathrm{P}$ values that were equilibrated with water isotopes, and nutrient concentrations. Simple linear regressions were performed to compare variables and analyze scatter plots visually. For these analyses, $\delta^{18} \mathrm{O}_{\mathrm{PO} 4}$ of tile drainage water was the dependent variable $(y)$, and nutrient concentrations and wetness index were the independent variables $(x)$.

\section{RESULTS AND DISCUSSION \\ INTRA-EVENT VARIABILITY OF TILE DRAIN PhOSPHATE OXYGEN ISOTOPE SIGNATURES}

Tile drain $\delta^{18} \mathrm{O}_{\mathrm{PO} 4}\left(\delta^{18} \mathrm{O}_{\mathrm{PO} 4-\mathrm{Drain}}\right)$ showed marked variation over the course of the monitored storm event (fig. 2b). Preceding the storm event (zone 1), $\delta^{18} \mathrm{O}_{\text {PO4-Drain }}$ averaged $16.3 \%$, which decreased to $14.9 \%$ at the onset of soil wetting (zone 2). A rapid increase in $\delta^{18} \mathrm{O}_{\text {PO4-Drain was found be- }}$ tween zones 2 and 3 (with $\delta^{18} \mathrm{OPO}_{\mathrm{P}-\mathrm{Drain}}$ increasing from 16\% to $17.5 \%$ ). Over the course of the falling limb of the hydrograph (zone 4$), \delta^{18} \mathrm{O}_{\mathrm{PO} 4-\text { Drain }}$ decreased slightly and averaged $17.0 \%$ until tile discharge returned to baseflow levels (zone 5) where $\delta^{18} \mathrm{OPO}_{\text {POrain }}$ increased to $18.0 \%$.
The 3.5\% fluctuation of $\delta^{18} \mathrm{O}_{\mathrm{PO}}$-Drain within the monitored storm event was significant given the amount of variation in phosphate isotope signatures reported in previous studies. For example, Gooddy et al. (2016) found that $\delta^{18} \mathrm{O}_{\mathrm{PO} 4}$ values over a $200 \mathrm{~m}$ stream reach with multiple source inputs, including a wastewater treatment plant and livestock farm, only varied by $2.0 \%$ o to $2.8 \%$ o during low flow and high flow sampling, respectively. Similarly, during a longitudinal river survey in southwest England, Granger et al. (2017) found that $\delta^{18} \mathrm{O}_{\mathrm{PO} 4}$ signatures in tributaries and along the main stem of the river only varied by $1.7 \%$. Given the broad range in $\delta^{18} \mathrm{O}_{\text {PO4-Drain }}$ observed during the current study and the limited source variability of $\mathrm{P}$ isotope signatures (discussed later), the results suggest that the temporal variation in $\delta^{18} \mathrm{O}_{\mathrm{PO} 4}$ signatures from drainage waters can be as large (or larger) than the spatial variability associated with multiple source contributions, and thus may provide important insight into $\mathrm{P}$ processes and cycling.

\section{Relationship between Drainage Phosphate OXYGEN ISOTOPES, NUTRIENT CONCENTRATION, AND SOIL MOISTURE \\ Nutrient Concentration}

Nutrient concentrations measured in tile drain discharge displayed broad and periodically contrasting gradients during the monitored storm event (fig. 2c). Average concentra-

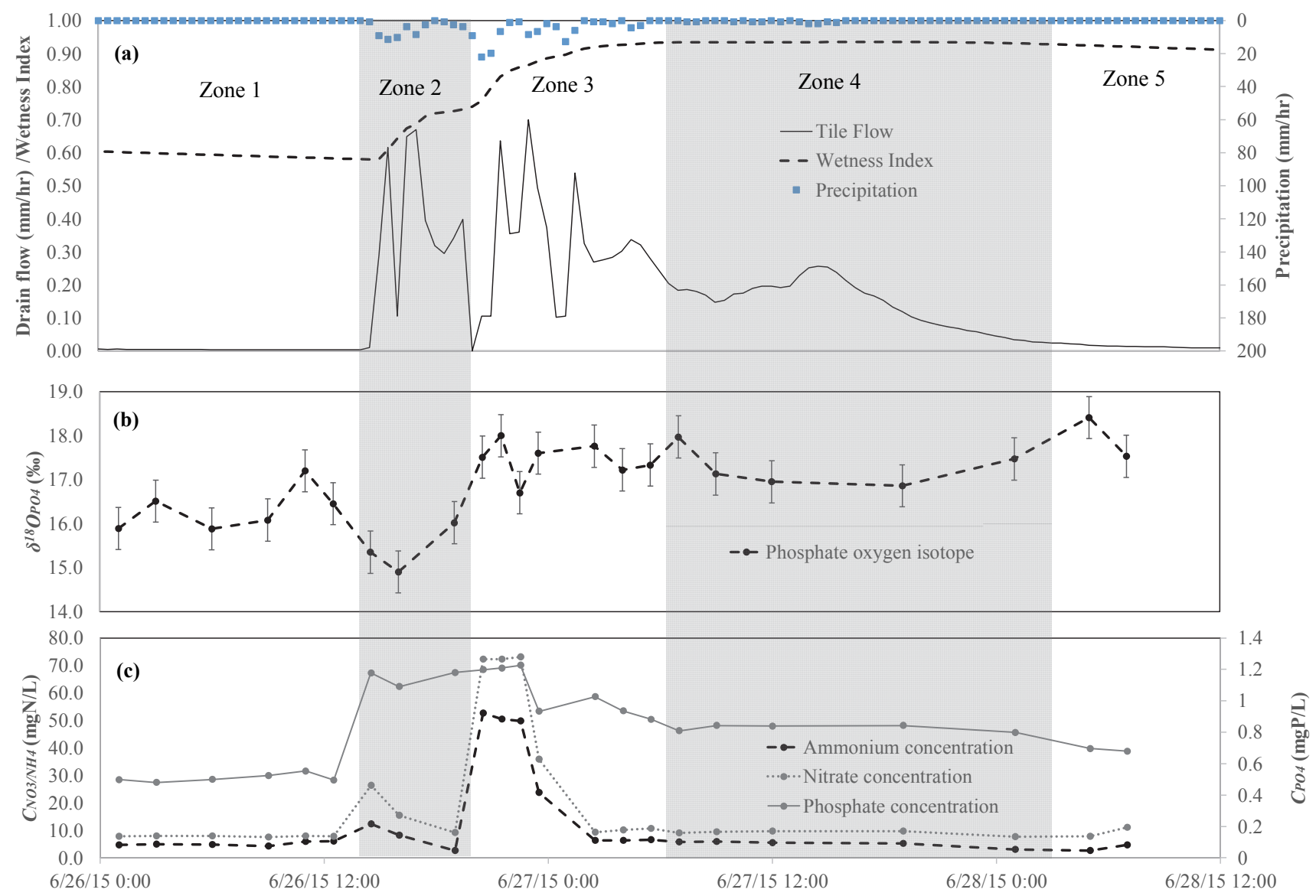

Figure 2. Time series of tile drainage measurements and model results including (a) hydrologic parameters including precipitation, tile drain flowrate, and wetness index, (b) P stable oxygen isotope signatures of composited water samples, and (c) nutrient concentration variables $\left(\mathrm{NO}_{3}\right.$, $\mathrm{NH}_{4}$, and $\mathrm{PO}_{4}-\mathrm{P}$ ). Different zones are highlighted to reflect (1) pre-event, (2) matrix re-wetting, (3) saturated conditions with peak flow, (4) receding limb, and (5) post-event. 
tions for DRP, $\mathrm{NO}_{3}-\mathrm{N}$, and $\mathrm{NH}_{4}-\mathrm{N}$ were $0.83,19.43$, and $12.3 \mathrm{mg} \mathrm{L}^{-1}$, respectively. During both pre-event and postevent baseflow, DRP, $\mathrm{NO}_{3}-\mathrm{N}$, and $\mathrm{NH}_{4}-\mathrm{N}$ were less than average concentrations. The initial wetting of the soil matrix on the rising limb of the hydrograph was characterized by maximum DRP concentration (1.1 to $1.2 \mathrm{mg} \mathrm{L}^{-1}$ ) and moderately low values of inorganic $\mathrm{N}\left(16.7 \mathrm{mg} \mathrm{NO}_{3}-\mathrm{N} \mathrm{L}^{-1}\right.$ and $7.8 \mathrm{mg} \mathrm{NH}_{4}-\mathrm{N} \mathrm{L}^{-1}$ ) relative to average concentrations for the event. Following peak DRP concentration on the rising limb, DRP concentration remained elevated $\left(1.2 \mathrm{mg} \mathrm{L}^{-1}\right)$ through peak flow and then decreased to $0.88 \mathrm{mg} \mathrm{L}^{-1}$ on the falling limb of the hydrograph. Inorganic $\mathrm{N}$ (both $\mathrm{NH}_{4}-\mathrm{N}$ and $\mathrm{NO}_{3}-$ $\mathrm{N}$ ) concentrations sharply increased (up to a cumulative value of $125 \mathrm{mg} \mathrm{L}^{-1}$ ) during peak flow and then rapidly decreased to pre-event baseflow levels. Throughout the falling limb of the hydrograph, DRP concentration remained stable $\left(\sim 0.84 \mathrm{mg} \mathrm{L}^{-1}\right)$, and the cumulative inorganic $\mathrm{N}$ concentration remained at pre-event baseflow levels $\left(\sim 14 \mathrm{mg} \mathrm{L}^{-1}\right)$.

Comparison of $\delta^{18} \mathrm{OPO}_{\mathrm{P}-\mathrm{Drain}}$ signatures with tile drain nutrient concentrations using linear regression resulted in weak correlation. Values of $\delta^{18} \mathrm{O}_{\text {PO4-Drain }}$ were not significantly related to $\mathrm{NO}_{3}-\mathrm{N}$ concentration $\left(y=0.01 x+16.76 ; \mathrm{R}^{2}=0.03\right.$; $\mathrm{p}>0.05), \mathrm{NH}_{4}-\mathrm{N}$ concentration $\left(y=0.01 x+16.75 ; \mathrm{R}^{2}=\right.$ $0.04 ; \mathrm{p}>0.05)$, or DRP concentration $(y=0.19 x+16.74$; $\mathrm{R}^{2}=0.00 ; \mathrm{p}>0.05$ ). Poor relationships between DRP concentration and $\delta^{18} \mathrm{O}_{\mathrm{PO} 4}$ signatures have been reported previously (e.g., Elsbury et al., 2009; Granger et al., 2017). However, Gooddy et al. (2016) reported a significant positive relationship between $\delta^{18} \mathrm{O}_{\mathrm{PO} 4}$ signature and DRP concentration in river water during low flow and a significant negative relationship between $\delta^{18} \mathrm{O}_{\mathrm{PO} 4}$ signature and DRP concentration during high flow. These results suggest that in some instances (or at some study sites) P source signature and magnitude of DRP concentration may be explicitly linked, but they may be decoupled in others.

\section{Soil Moisture}

Model calibration and validation results for the WALRUS model simulation are provided in figures 3 and 4, respectively, with calibrated model parameters provided in the bottom right corner of each figure. Results of the optimization resulted in a maximum daily NSE value of 0.5 for calibration and 0.3 for validation at a daily timestep. These statistics decreased slightly when an hourly timestep for calibration was used (NSE $=0.4$ ) and remained the same for validation (NSE $=0.3)$. An NSE $>0.5$ for calibration has been characterized as satisfactory for monthly timestep evaluation of field-scale flow modeling (Moriasi et al., 2007). However, calibration statistics are often relaxed at smaller timesteps (i.e., weekly, daily, hourly). For instance, Moriasi et al. (2007) identified several studies with NSE values exceeding 0.5 at monthly timesteps that had NSE $<0.5$ at daily timesteps. As an example, Fernandez et al. (2005) found NSE values of 0.664 for monthly simulation of DRAINMOD-W that dropped to 0.363 when evaluated on a daily timestep. Visually, we were able to accurately capture several runoff events outside of the calibration period, despite the drop in NSE (fig. 4). As part of the validation process, the behavior of the groundwater table was qualitatively eval-

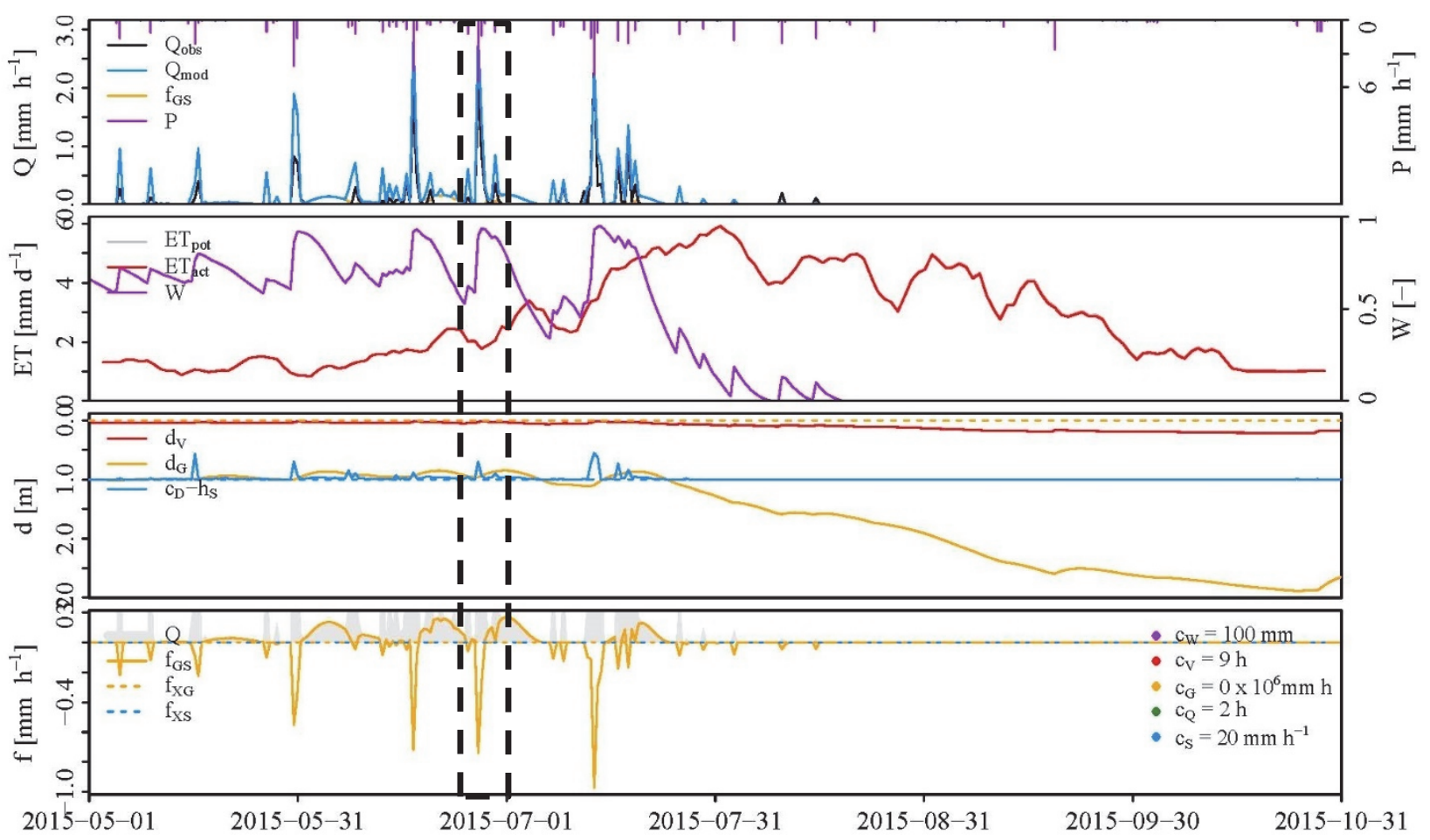

Figure 3. Calibration of the WALRUS model for the growing season. Plots are generated from the software simulated in R as discussed by Brauer et al. (2014). Plotted model outputs and forcing data include discharge $(Q)$, precipitation $(P)$, evapotranspiration (ET), wetness index ( $W$ ), storage

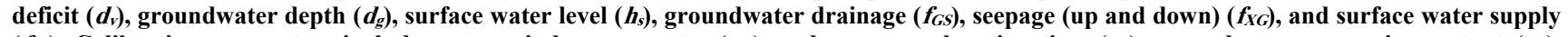
$\left(f_{x} s\right)$. Calibration parameters include wetness index parameter $\left(c_{w}\right)$, vadose zone relaxation time ( $\left.c_{v}\right)$, groundwater reservoir constant $\left(c_{G}\right)$, quickflow reservoir constant $\left(c_{Q}\right)$, and a surface water parameter (cs). Refer to Brauer et al. (2014) for description of the model theory and numerical framework. As a reference, the area inside the dashed box highlights the storm event monitored in June 2015 for nutrient concentration and phosphate isotope analysis 


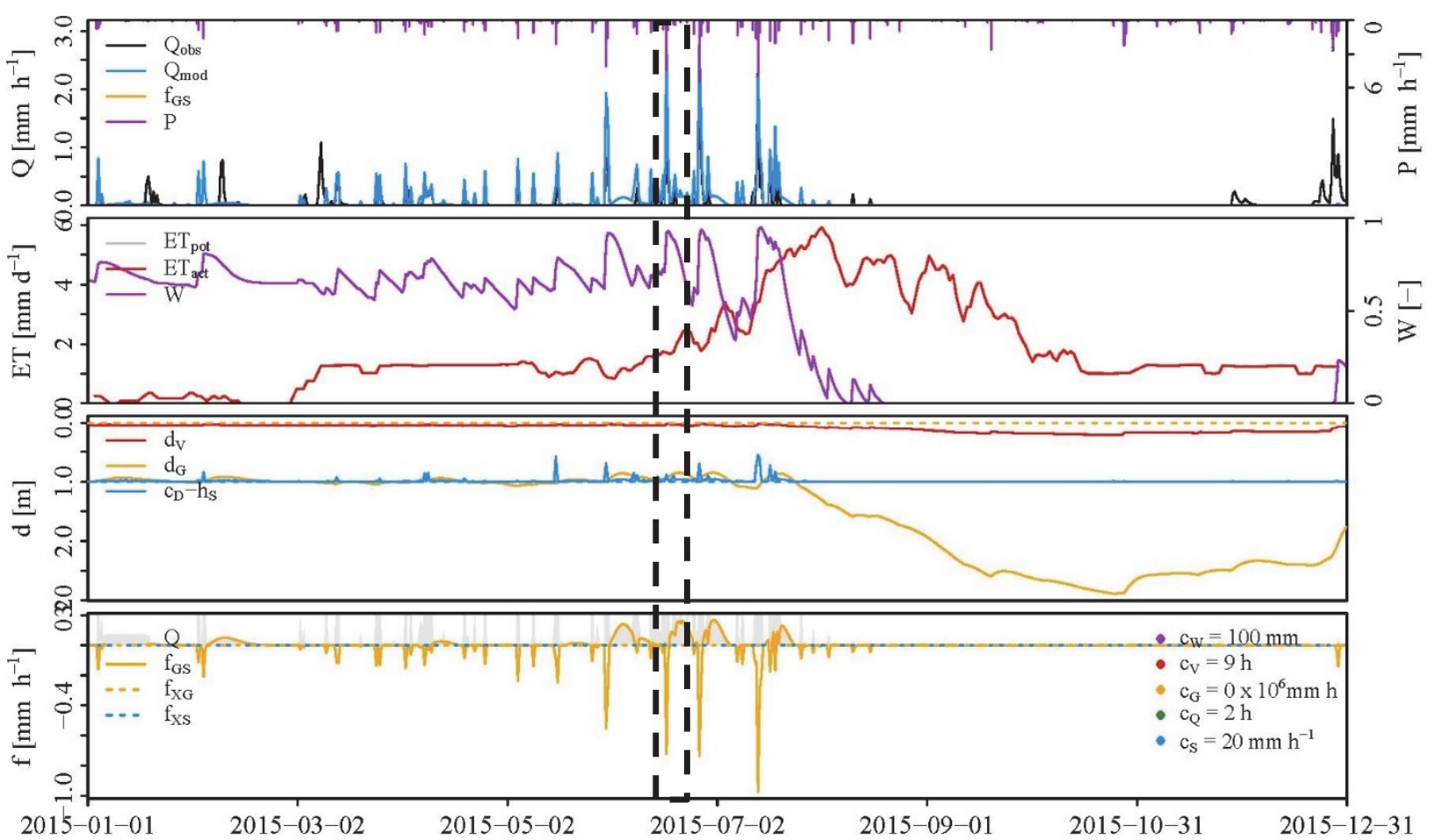

Figure 4. Validation of the WALRUS model for the 2015 calendar year. Plots are generated from the software simulated in $\mathbf{R}$ as discussed by Brauer et al. (2014). Plotted model outputs and forcing data include discharge $(Q)$, precipitation $(P)$, evapotranspiration $(E T)$, wetness index ( $W$, storage deficit $\left(d_{v}\right)$, groundwater depth $\left(d_{g}\right)$, surface water level $\left(h_{s}\right)$, groundwater drainage ( $\left.f_{G S}\right)$, seepage (up and down) $\left(f_{X G}\right)$, and surface water supply $\left(f_{X s}\right)$. Calibration parameters include wetness index parameter $\left(c_{W}\right)$, vadose zone relaxation time $\left(c_{V}\right)$, a groundwater reservoir constant $\left(c_{G}\right)$, quickflow reservoir constant $\left(c_{Q}\right)$, and a surface water parameter $\left(c_{s}\right)$. Refer to Brauer et al. (2014) for description of the model theory and numerical framework. As a reference, the area inside the dashed box highlights the storm event monitored in June 2015 for nutrient concentration and phosphate isotope analysis.

uated to ensure realistic dynamics. Model results showed that the groundwater table oscillated above and below the tile drainage depth during the wet season, dipped below the tile drain depth in the dry season, and was subsequently replenished at the end of the year (fig. 4). These results support that our model was adequate for assessing soil moisture variability, which was the main objective of the model application. While a formal uncertainty analysis of the model was not performed, the wetness index $(W)$ had consistent trends for our monitored storm event, regardless of the parameterization of boundary conditions and soil type; therefore, we do not anticipate the interpretation of our results to change under alternative parameterizations.

Results for $W$ during the storm event showed moderate soil moisture content at the beginning of the event that increased to fully saturated conditions by the end of the event (fig. 2a). It is important to first note that the event occurred during a wet portion of the year. The average $W$ value for June was 0.72 , which far exceeded the annual average of 0.39 (fig. 4). In the two weeks preceding the monitored storm event, the field received $130 \mathrm{~mm}$ of precipitation, which constitutes $>10 \%$ of the site's annual precipitation. As a result, $W$ during pre-event baseflow was above average for the year and ranged from 0.5 to 0.6 . The onset of precipitation resulted in increased soil moisture storage, which increased $W$ from 0.6 to 0.72 on the rising limb of the storm hydrograph. Continued precipitation led to saturated soil moisture conditions with a maximum $W$ of 0.91 occurring near peak tile flow. A slow recession of the $W$ parameter oc- curred throughout the falling limb of the hydrograph, with a final value of 0.88 .

Linear regression between $\delta^{18} \mathrm{O}_{\mathrm{PO} 4-\text { Drain }}$ signatures and $W$ showed a strong positive relationship during the monitored storm event (fig. 5), which suggests that fluctuations in $\delta^{18} \mathrm{O}_{\text {PO4-Drain }}$ signatures were dynamically linked to changes in field soil moisture status. While several studies have reported differences in $\delta^{18} \mathrm{O}_{\mathrm{PO} 4}$ under contrasting flow conditions, results from the current study are the first to show that changing soil moisture conditions during a storm event may influence $\delta^{18} \mathrm{OPO}_{\mathrm{PO}}$ in drainage water. Future research investigating the relationship between $\delta^{18} \mathrm{O}_{\mathrm{PO} 4}$ and $W$ over broader timescales (seasonal to annual) is warranted, given the key role that soil moisture has on flow pathways through the soil profile, microbial activity, and nutrient transport.

\section{Soll Water-Extractable Phosphorus CONCENTRATION AND PHOSPHATE OXYGEN ISOTOPES}

Average soil WEP concentrations were $>2.21 \mathrm{mg} \mathrm{P} \mathrm{kg}{ }^{-1}$ in the top $20 \mathrm{~cm}$ of the soil profile, and average concentrations were $<0.19 \mathrm{mg} \mathrm{P} \mathrm{kg}^{-1}$ between 20 and $80 \mathrm{~cm}$ depths (fig. 6). Phosphorus stratification within the soil profile is common in agroecosystems (e.g., Baker et al., 2017) and likely reflects the historical nutrient management practices at the field site in which years of poultry litter application followed by tillage increased $\mathrm{P}$ concentrations in the plow layer $(0-20 \mathrm{~cm})$. Soil WEP $\delta^{18} \mathrm{O}_{\mathrm{PO} 4}$ values (i.e., $\left.\delta^{18} \mathrm{O}_{\mathrm{PO} 4 \text {-WEP }}\right)$ were measured for the $0-5 \mathrm{~cm}(n=6)$ and $5-20 \mathrm{~cm}(n=6)$ 


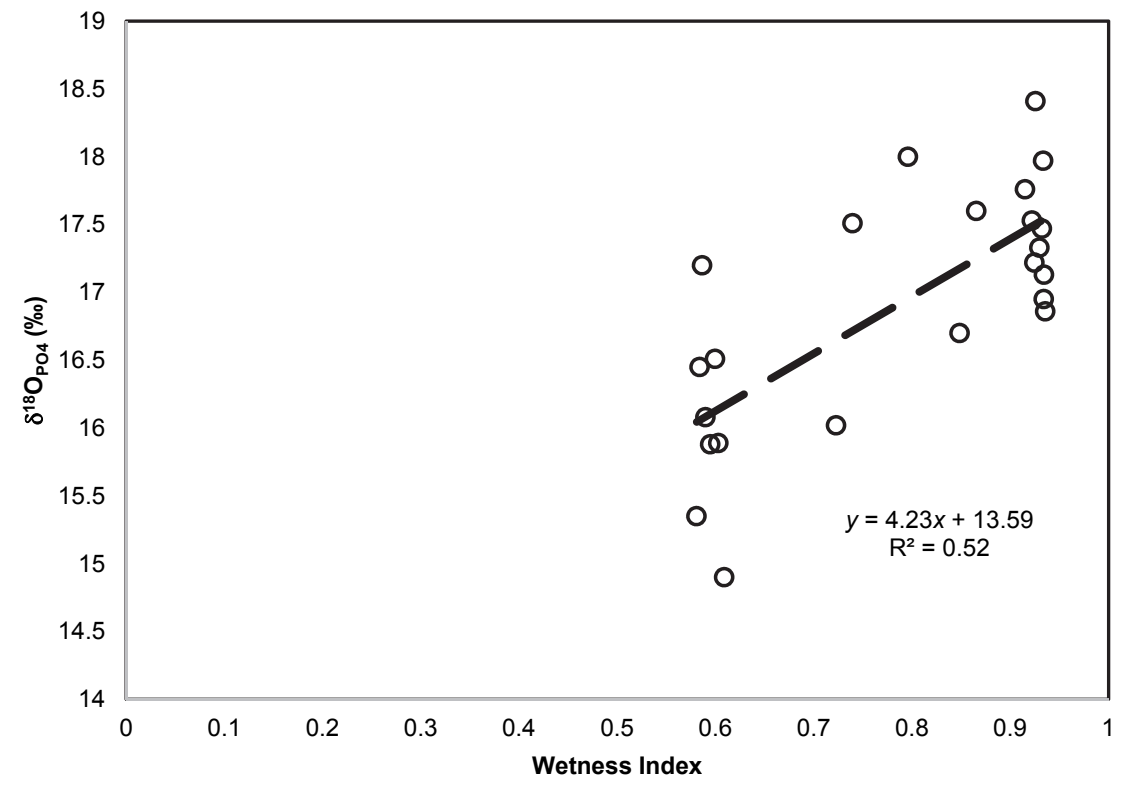

Figure 5. Scatterplots and linear regression analysis of tile-drain phosphate oxygen isotope measurements with the modeled values for soil water wetness $(W)$ index.
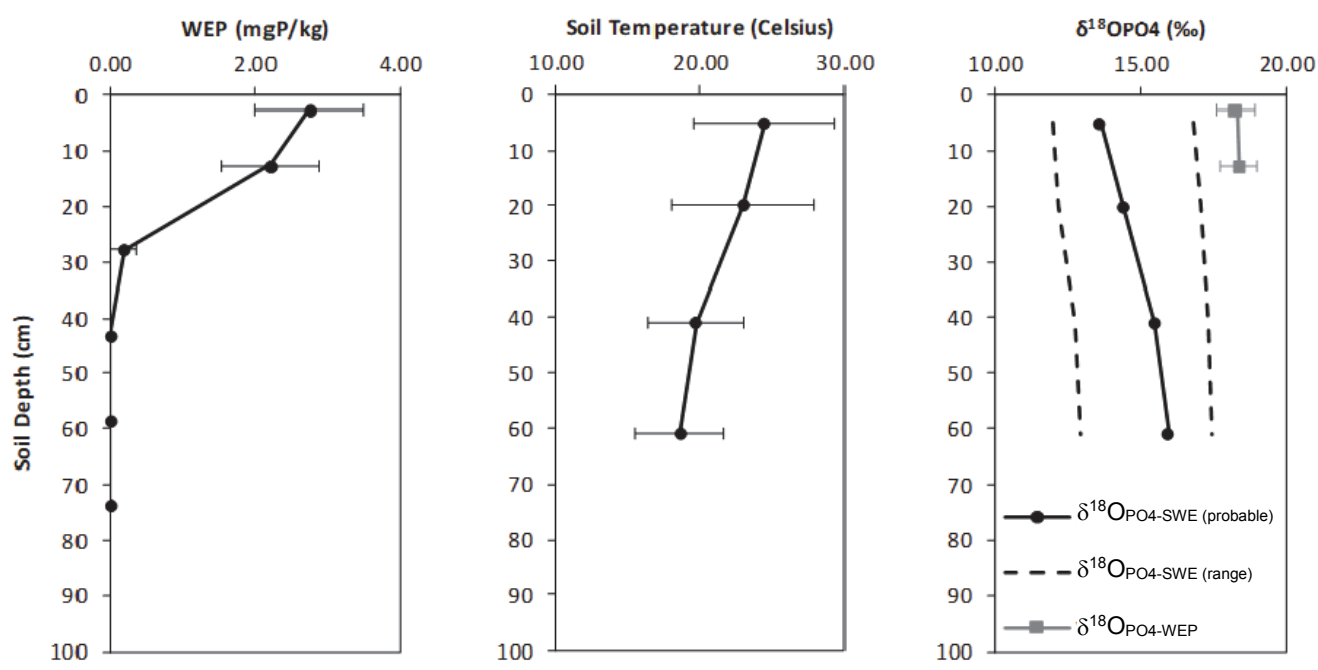

Figure 6. Vertical profile characteristics including water-extractable $P(W E P)$, soil temperature gradients (averaged from a nearby site in DeKalb County, Indiana), estimated soil water equilibrium (SWE) phosphate isotope signatures for pore water in the vadose zone, and stable oxygen isotope composition of WEP. Error bars reflect \pm 1 standard deviation of datasets.

depths and averaged $18.3 \%$ and $18.4 \%$, respectively (fig. 2c). We did not obtain isotopic signatures for soil WEP below $20 \mathrm{~cm}$ because concentrations were an order of magnitude smaller than the upper $20 \mathrm{~cm}$. Results of Student's ttest to compare soil WEP concentrations and $\delta^{18} \mathrm{O}_{\text {PO4-WEP }}$ signatures between the $0-5 \mathrm{~cm}$ and $5-20 \mathrm{~cm}$ depths indicated no significant difference $(\mathrm{p}>0.05)$ between depths for either parameter.

Calculation of microbially mediated isotopic equilibrium is important for quantifying the non-conservative behavior of $\delta^{18} \mathrm{O}_{\mathrm{PO} 4}$ signatures in the WEP pool and can provide insight into source deviations from the original signatures. Expected isotopic equilibrium of $\delta^{18} \mathrm{O}_{\mathrm{PO}}$ in the WEP pool with soil water was calculated using a conservative range of literature-derived $\delta^{18} \mathrm{O}_{\mathrm{H} 2 \mathrm{O}}$ signatures for drainage waters in the region $(-10 \%$ o to $-6 \%$ ) and measured long-term soil temperatures from the nearby study site $\left(12.8^{\circ} \mathrm{C}\right.$ at $5 \mathrm{~cm} ; 14.7^{\circ} \mathrm{C}$ at $20 \mathrm{~cm})$. Calculated results showed that expected isotopic equilibrium would be between $13.6 \%$ and $17.9 \%$. Thus, average $\delta^{18} \mathrm{O}_{\text {PO4-WEP }}$ signatures were $0.4 \%$ to $4.7 \%$ greater than expected isotopic equilibrium values. While the estimate is overly conservative, the equilibrium values for this broad uncertainty range do not overlap with the range of measured soil WEP $\delta^{18} \mathrm{O}_{\mathrm{PO} 4}$ values. This finding suggests that the surface soils reflected, to some degree, the original source of P (poultry litter) that was applied to the field more 
than ten years before the monitored event. Previous studies examining soil WEP have found mixed results regarding $\delta^{18} \mathrm{OPO}_{\text {PO-WEP }}$ establishing equilibrium with soil water $\delta^{18} \mathrm{O}_{\mathrm{H} 2 \mathrm{O}}$ (Tamburini et al., 2012; Joshi et al., 2016; Zohar et al., 2010a.). For instance, Joshi et al. (2016) observed that following fertilizer application $(38 \%) \delta^{18} \mathrm{O}_{\text {PO4-WEP }}(0-2 \mathrm{~cm}$ depth) was $\sim 10 \%$ lighter (approaching equilibrium) after 18 days and in complete equilibrium with soil water $\delta^{18} \mathrm{O}_{\mathrm{H} 2 \mathrm{O}}$ after 155 days. However, soil nutrient status may influence microbial P intracellular cycling (Gross et al., 2015). Examining changes in soil $\delta^{18} \mathrm{O}_{\mathrm{PO} 4}$ between plots that had received no $\mathrm{P}$ inputs and plots receiving chronic $\mathrm{P}$ additions, Gross et al. (2015) found that bioavailable soil $\delta^{18} \mathrm{O}_{\mathrm{PO} 4}$ for the plots receiving chronic $\mathrm{P}$ additions was only slightly deviated from the value of the added $P$ compound, while values approached equilibrium for the no-P plots. Given the elevated soil WEP concentrations in the current study, it is likely that the microbial biomass was not P-limited, resulting in retention of the original $\delta^{18} \mathrm{O}_{\mathrm{PO} 4}$ signature of the poultry manure source. Because fields with high soil test $\mathrm{P}$ concentrations are recognized hotspots of DRP delivery at watershed scales (Baker et al., 2017), $\delta^{18} \mathrm{O}_{\mathrm{PO} 4}$ may be a useful indicator for targeted watershed nutrient management strategies by characterizing spatial variability in soil WEP pools.

Because $\delta^{18}$ OPO4-WEP was not within the range of expected isotopic equilibrium values, expected soil water equilibrium (SWE) $\delta^{18} \mathrm{O}_{\mathrm{PO} 4}$ (i.e., $\delta^{18} \mathrm{O}_{\mathrm{PO} 4-\mathrm{SWE}}$ ) signatures could potentially serve as an additional end-member for understanding $\delta^{18} \mathrm{O}_{\text {PO4-Drain }}$ dynamics during the storm event. Values of $\delta^{18} \mathrm{O}_{\mathrm{PO} 4-\mathrm{SWE}}$ were calculated by varying soil temperature and soil water $\delta^{18} \mathrm{O}_{\mathrm{H} 2 \mathrm{O}}$ by depth, with a typical $\delta^{18} \mathrm{O}_{\text {PO4-SwE }}$ profile developed for the study site. Using this approach, results showed that soil temperature variability with depth can exert a strong control on $\delta^{18} \mathrm{O}_{\mathrm{PO} 4-\mathrm{SWE}}$ signatures. Temperature gradients in the soil profile alone resulted in a $0.6 \%$ to $1 \%$ increase in the expected $\delta^{18} \mathrm{OPO}_{\mathrm{PO} \text {-SWE }}$ from the 5 to $60 \mathrm{~cm}$ depth (fig. 6). Values of $\delta^{18} \mathrm{O}_{\mathrm{PO} 4-\mathrm{SWE}}$ shown in figure 6 reflect an overly conservative range of typical $\delta^{18} \mathrm{O}_{\mathrm{H} 2 \mathrm{O}}$ values for preevent water in drainage waters in the region $(-10 \%$ to $-6 \%$; Kendall et al., 2001; Dutton et al., 2005; Vidon and Caudra, 2010; Williams et al., 2016a) and soil temperatures at which equilibration could occur. As such, expected equilibrium values of $\delta^{18} \mathrm{OPO4-SWE}_{\mathrm{SW}}$ throughout the soil profile ranged from $11.9 \%$ o $\left(\right.$ depth $=5 \mathrm{~cm}$, temperature $=25.5^{\circ} \mathrm{C}, \delta^{18} \mathrm{O}_{\mathrm{H} 2 \mathrm{O}}=$ $-10 \%$ ) to $17.5 \%$ o (depth $=60 \mathrm{~cm}$, temperature $=15.27^{\circ} \mathrm{C}$, $\delta^{18} \mathrm{O}_{\mathrm{H} 2 \mathrm{O}}=-6 \%$ ). It is of interest that even when using these overly conservative ranges of soil temperature and soil water $\delta^{18} \mathrm{O}_{\mathrm{H} 2 \mathrm{O}}$ values, the $\delta^{18} \mathrm{O}_{\mathrm{PO} 4-\mathrm{SWE}}$ range did not overlap with measured $\delta^{18} \mathrm{OPO}_{\mathrm{P}-\mathrm{WEP}}$ values; however, it overlapped with the range in values for $\delta^{18} \mathrm{O}_{\mathrm{PO} 4-\mathrm{Drain}}$. Additionally, $\delta^{18} \mathrm{O}_{\mathrm{PO} 4}$ SWE at shallow and deeper soil depths also exhibited distinct ranges in values. To establish a typical $\delta^{18} \mathrm{OPO}_{\mathrm{P}-\mathrm{SWE}}$ profile for the study site, an average precipitation value of $\delta^{18} \mathrm{O}_{\mathrm{H} 20}$ was assumed to be $-9 \%$ (Dutton et al., 2005), and soil water $\delta^{18} \mathrm{O}_{\text {н2О }}$ at the bottom of the root zone (where evapotranspiration reaches zero) was assumed to equal an average preevent value of $-7.3 \%$ (average of nearby pre-event water from tile drains) (fig. 6). Because much of the evapotranspiration for maize occurs in the top half of the root zone, we assumed that $70 \%$ of the water isotope fractionation occurred linearly in the first $30 \mathrm{~cm}$ of the profile, and the remaining $30 \%$ occurred in the lower $30 \mathrm{~cm}$ of the root zone (USDA-NRCS, 1997).

\section{USING PHOSPHATE OXYGEN ISOTOPES TO ASSESS DRP FATE AND TRANSPORT IN DRAINED LANDSCAPES}

Combining measured values of nutrient concentration, $\delta^{18} \mathrm{O}_{\text {PO4-Drain }}$, and $\delta^{18} \mathrm{O}_{\text {PO4-WEP }}$ with modeled soil moisture status $(W)$ and estimated $\delta^{18} \mathrm{O}_{\mathrm{PO}} \mathrm{SWWE}$, potential $\mathrm{P}$ sources and flow pathways at the study site were inferred for the five zones of the monitored storm event. Results highlight the potential for $\delta^{18} \mathrm{O}_{\mathrm{PO} 4}$ to serve as a valuable tracer to help quantify DRP fate and transport in tile-drained landscapes.

\section{Pre-Event Baseflow (Zone 1)}

During the time preceding the monitored storm event, nutrient concentrations $\left(\mathrm{NO}_{3}-\mathrm{N}, \mathrm{NH}_{4}-\mathrm{N}\right.$, and DRP) were low relative to concentrations later in the event, and $\delta^{18} \mathrm{OPO}_{\mathrm{PO} \text {-Drain }}$ values averaged $16.3 \%$. Values of $\delta^{18} \mathrm{O}_{\text {PO4-Drain }}$ were similar to the estimated $\delta^{18} \mathrm{O}_{\mathrm{PO}}$-SWE values at deeper depths in the soil profile. Because pre-event tile water often reflects diffuse matrix percolation, DRP that was transported through the soil matrix between the monitored event and the previous event (June 16) had likely equilibrated to expected temperature and water isotope dependent values as a result of microbial $\mathrm{P}$ cycling. Similar rates of microbial $\mathrm{P}$ cycling overwriting original source signatures (i.e., $\delta^{18} \mathrm{O}_{\mathrm{PO} 4-W E P}$ for the field in the current study) have been observed in several studies using $\delta^{18} \mathrm{O}_{\mathrm{PO} 4}$ (Zohar et al., 2010a, 2010b; Tamburini et al., 2012; Joshi et al., 2016).

\section{Rising Limb of Hydrograph (Zone 2)}

Moderate values of $W(0.55$ to 0.72$)$ and $\delta^{18} \mathrm{O}_{\mathrm{PO} 4 \text {-Drain }}$ values (as low as $14.9 \%$ ) becoming increasingly similar to $\delta^{18}$ OPO4-Swe values at shallow depths in the soil profile suggest increased connectivity between near-surface soils and the tile drain during zone 2 (fig. 2 b). Changes in $\delta^{18} \mathrm{O}_{\text {PO4-Drain }}$ on the rising limb of the hydrograph coincided with large increases in DRP concentration (1.1 to $\left.1.2 \mathrm{mg} \mathrm{L}^{-1}\right)$ and slight increases in the combined inorganic $\mathrm{N}$ concentration (13 to $40 \mathrm{mg} \mathrm{L}^{-1}$ ) relative to baseflow (fig. 2c). Numerous studies have observed large increases in DRP concentration on the rising limb of the hydrograph (King et al., 2015b), which has led to the prevailing hypothesis in the literature that DRP transport to tile drains is largely the result of macropore flow.

Results from the current study suggest that much of the DRP delivered to the tile drains in zone 2 of the hydrograph was through unsaturated macropore flow pathways initiated by advancement of the wetting front in near-surface soils. Previous studies have found that unsaturated macropore flow is often initiated at the soil surface either due to surface ponding or surface saturation (Weiler and Naef, 2003; Dahlke et al., 2012; Mirus and Nimmo, 2013; Klaus et al., 2013; Ford et al., 2017). Examining flow and P transport on 
a hillslope, Dahlke et al. (2012) found that under wet antecedent conditions (similar to our study) $\mathrm{P}$ that had accumulated in the shallow subsurface as a result of past fertilizer applications was mobilized during storm events with water stored in the soil matrix prior to the event (i.e., pre-event or old water). For our case study, we postulate that surface saturation and mobilization of the wetting front over the first few hours of the event led to matrix-macropore interaction and subsequently high DRP concentrations in the tile drain. Small increases in dissolved inorganic N concentration within zone 2 support our hypothesis. Given the recent application of inorganic $\mathrm{N}$ fertilizer, we would have suspected peak concentrations of $\mathrm{N}$ (as found in zone 3) if soil water was the sole source of preferential flow during this stage of the hydrograph; however, the moderate $\mathrm{N}$ concentrations (relative to other concentrations during the monitored event) likely reflect some level of mixing of precipitation (low in $\mathrm{N}$ ) with soil water (enriched in leached $\mathrm{NO}_{3}$ and $\mathrm{NH}_{4}$ ) delivered to the unsaturated macropores. This result is further supported by a nearby watershed-scale study in Indiana, which highlighted that increased drainage density leads to a higher proportion of near-surface storm event water early in the hydrograph (Kennedy et al., 2012).

It is important to note that our study results show that $\delta^{18} \mathrm{O}_{\text {PO4-Drain }}$ on the rising limb was more like shallow

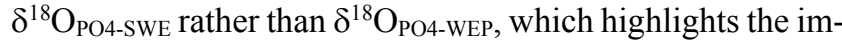
portance of mobilization of previously leached DRP that resides in the matrix, as opposed to newly leached WEP. As such, DRP transported in unsaturated macropore flow pathways was $\mathrm{P}$ that was previously released into the soil solution (likely from the original source $\left(\delta^{18} \mathrm{O}_{\text {PO4-WEP }}\right)$ during the previous event) and then cycled by microbial biomass. Thus, the length of time and the antecedent soil moisture conditions (e.g., $W$ ) between storm events may influence $\delta^{18}$ OPO4-Drain values, maximum DRP concentration, and the utility of $\delta^{18} \mathrm{O}_{\mathrm{PO} 4}$ as a tracer of $\mathrm{P}$ sources. For instance, increasing DRP concentration (up to $3 \mathrm{mg} \mathrm{L}^{-1}$ ) from the same tile drain monitored in this study has been observed during a series of storm events (King et al., 2016). We postulate that increasing maximum DRP concentration during a series of storm events may be due to a combination of factors in the shallow subsurface layer, e.g., change in redox potential (see Rupp et al., 2004), which leads to high leaching in a prior event and then an initial flush at the beginning of the subsequent event through macropore pathways.

\section{Peak Flow (Zone 3)}

Our results indicate that DRP in the near-surface soil matrix was mobilized from the soil WEP pool under saturated conditions and subsequently transported to tile drains in zone 3 . As soil wetness increased, $\delta^{18} \mathrm{O}_{\mathrm{PO}}$-Drain also increased relative to the rising limb of the hydrograph (16.5\%o to $18 \%$ ) and approached values similar to $\delta^{18}$ OPO4-WEP. We highlight the plausibility of saturated macropores becoming activated because $\delta^{18} \mathrm{O}_{\mathrm{PO}}$-Drain was consistent with expected $\delta^{18} \mathrm{OPO}_{\text {POSWE }}$ values at deep soil depths prior to the event and shallow soil depths on the rising limb of the hydrograph, and then remained bounded between $\delta^{18} \mathrm{O}_{\mathrm{PO} 4-W E P}$ and expected $\delta^{18} \mathrm{O}_{\mathrm{PO} 4-\mathrm{SWE}}$ at deeper depths in the soil profile throughout the rest of the event (zones 4 and 5), suggesting mixture of old and new water. Therefore, we would not suspect that matrix percolation would be the pathway of newly leached $\mathrm{P}$ from surface soils during this stage of the event. Similarly, Klaus et al. (2014) found that immobilized pesticides in shallow soil layers were released under saturated conditions and delivered to tile drains via saturated macropore flow. Based on the historical poultry litter application at the field in the current study, results suggest that $\delta^{18} \mathrm{O}_{\mathrm{PO} 4-\text { Drain }}$ revealed the release and transport of legacy $\mathrm{P}$ within the monitored storm event.

Patterns of nutrient concentrations, $\delta^{18} \mathrm{O}_{\mathrm{PO} 4-\text { Drain }}$, and $W$ indicate that unsaturated macropore flow observed on the rising limb of the hydrograph had transitioned to predominately saturated macropore flow during peak rainfall and flow periods. Saturated macropore flow has been shown to consist of both pre-event water and event water due to the interaction between matrix and macropore flow pathways (Klaus et al., 2013). The high DRP concentrations early in this stage of the hydrograph reflect direct connectivity to the near-surface. Later in zone 3, mixing of event water with elevated DRP concentration from the near-surface with higher proportions of pre-event matrix water deeper in the vadose zone with low DRP concentration likely resulted in the observed decrease in DRP during this zone of the event. Similarly, the peak and decline in dissolved inorganic $\mathrm{N}$ concentration was consistent with preferential flow through saturated pathways and matrix-macropore interaction. Initially, saturated soil conditions in the shallow subsurface resulted in mobilization of recently applied $\mathrm{N}$ fertilizer stored on the surface and in the shallow soil matrix, which was followed by rapid transport to the tile drain in saturated macropores. Kennedy et al. (2012) observed similar patterns in $\mathrm{NO}_{3}-\mathrm{N}$ transport in tile-drained watersheds, where the maximum $\mathrm{NO}_{3}-\mathrm{N}$ concentration was observed following the hydrograph peak. The rapid drop in $\mathrm{N}$ concentrations coinciding with the drop in DRP concentrations reflects hydrologic disconnectivity with near-surface soils and enhanced connectivity with the deeper vadose zone through saturated macropore flow.

\section{Falling Limb of Hydrograph (Zone 4)}

Throughout the falling limb of the hydrograph, DRP concentration continued to slowly decrease, and dissolved inorganic $\mathrm{N}$ concentration returned to baseflow values (fig. 4). Soil wetness remained high $(W=0.9)$, and $\delta^{18} \mathrm{O}_{\mathrm{PO} 4-\mathrm{Drain}}$ decreased from $18 \%$ o to $16.9 \%$ and then increased (fig. 2a). High values of $W$, higher DRP concentration relative to baseflow, and greater $\delta^{18} \mathrm{O}_{\mathrm{PO} 4-\mathrm{Drain}}$ values than would be expected for $\delta^{18} \mathrm{OPO4}_{\text {-SWE }}$ gradients in the soil profile suggest that saturated macropores likely remained activated, especially early in zone 4 . Results suggest that decreasing $\delta^{18} \mathrm{O}_{\text {PO4-Drain }}$ during the initial part of zone 4 reflects percolation of a mixture of deep $\delta^{18} \mathrm{O}_{\text {PO4-SWE }}$ and $\delta^{18} \mathrm{O}_{\text {PO4-WEP. After }}$ 6:00 p.m. on June $27, \delta^{18} \mathrm{O}_{\mathrm{PO} 4-\mathrm{Drain}}$ increased, which likely reflects the dominance of $\delta^{18} \mathrm{O}_{\text {PO4-WEP }}$ transported through diffuse percolation through the soil matrix. A one-day lag time between peak rainfall and diffuse percolation of $\delta^{18} \mathrm{O}_{\mathrm{PO}}$-WEP from the soil surface to the depth of the tile drain 
is plausible for the fine-textured soil in this study. For example, Vidon and Cuadra (2010) noted that water would take at least $22 \mathrm{~h}$ to percolate through the soil matrix to tile drains through diffuse pathways.

\section{Post-Event Baseflow (Zone 5)}

During post-event baseflow, $\delta^{18} \mathrm{O}_{\text {PO4-Drain }}$ remained simi-

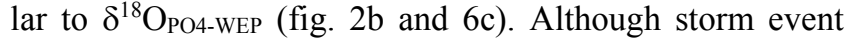
monitoring ceased as tile flow returned to baseflow values, as the soil profile began to dry we expect that microbial cycling would eventually overwrite the original source signature that was released during the event. Thus, given sufficient time, $\delta^{18} \mathrm{O}_{\mathrm{PO}} 4$-Drain would reflect deep $\delta^{18} \mathrm{O}_{\mathrm{PO}}$-SwE, as observed prior to the monitored event.

\section{IMPLICATIONS FOR DRP MANAGEMENT}

Results of our study indicate not only the utility of $\delta^{18} \mathrm{O}_{\text {PO4-Drain }}$ to inform perceptual models of DRP fate and transport but also improve management strategies at the field scale. To illustrate this point, we provide estimates of cumulative DRP load throughout each zone of the event (fig. 7). Event tile DRP load was calculated by summing the product of flow and nutrient concentration at a 30 min timestep over the course of the monitored event. Linear interpolation was used to determine DRP concentration between collected samples. Flow rate was obtained from the USDA edge-offield data. Cumulative load throughout the event was also calculated and normalized by dividing by total event load, such that values ranged from 0 to 1 . Results of the analysis show that nearly $100 \%$ of the load $(0.30 \mathrm{~kg} \mathrm{P})$ was delivered from the tile drains during zones 2 through 4 . Specifically, $30 \%(0.09 \mathrm{~kg} \mathrm{P})$ of the loading occurred in zone $2,40 \%$ $(0.12 \mathrm{~kg} \mathrm{P})$ in zone 3 , and $30 \%(0.09 \mathrm{~kg} \mathrm{P})$ in zone 4 . We emphasize the results for zone 2 , in which $18 \%$ of the tile flow contributed $30 \%$ of the DRP load. Our results suggest that this "hot moment" of DRP delivery originated from SWE-P and was transported via unsaturated macropore path- ways, highlighting the importance of antecedent leaching of $P$ to contribute significant fluxes during an event. Management strategies targeted at reducing the unsaturated macropore structure below the shallow soil surface prior to an event have potential to decrease these rapid fluxes by forcing water through tortuous matrix percolation. As an example, drainage water management (DWM) structures are widely used to maintain moisture in the field during the growing season to minimize the effect of drought on crop stress and have been shown to reduce DRP loads in tiledrained landscapes (Zhang et al., 2017); however, high water tables can adversely impact reducing conditions and $\mathrm{P}$ solubility in soils, resulting in an increase in DRP concentrations (King et al., 2015b, and references within). Based on the results of our study, we suspect that $\delta^{18} \mathrm{O}_{\mathrm{PO} 4-\mathrm{Drain}}$ could provide valuable insight for planning of drainage water management activities and is an area for future work.

\section{CONCLUSION}

In this study, a novel dataset of $\delta^{18} \mathrm{O}_{\mathrm{PO} 4}$ values collected during a large summer storm event from a tile-drained agricultural field was presented. Using a combination of $\delta^{18} \mathrm{O}_{\mathrm{PO} 4}$ values from tile drain water and soil water extracts, nutrient concentrations, soil temperatures, and soil water modeling, we were able to elucidate potential sources and flow pathways of DRP delivery to tile drains. Results show that elevated DRP concentrations observed during earlier matrix wetting periods were, at least partially, in isotopic equilibrium with shallow soil water and were likely transported via unsaturated macropore flow. As soil moisture increased during the event, DRP transport transitioned from unsaturated to saturated macropore flow pathways. Increasing soil moisture resulted in desorption of DRP from surface soils that likely resembled the original source of $P$ (poultry litter) that was applied to the field more than ten years before the monitored event. Findings indicate that $\delta^{18} \mathrm{O}_{\mathrm{PO} 4}$ therefore has

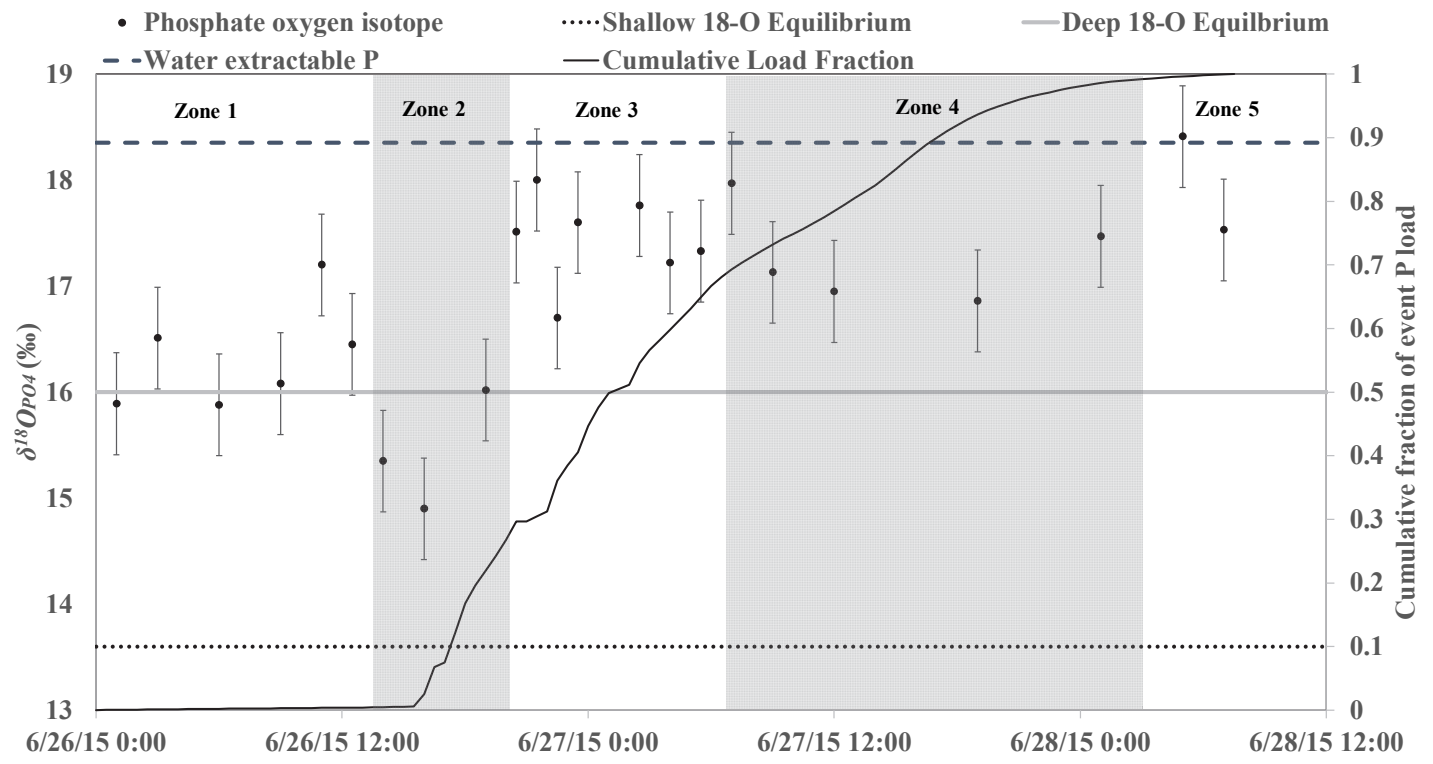

Figure 7. Cumulative load curve for DRP load during the June 2015 storm event. Horizontal lines reflect $\delta^{18} \mathrm{O}_{\mathrm{PO}}$ signatures of different DRP pathways during the event including WEP, shallow soil water, and deep soil water and are compared with the measured tile-drain $\delta^{18} \mathrm{O}_{\mathrm{PO} 4}$ signatures ( \pm 1 standard deviation). 
utility for tracing DRP fate and transport in tile-drained agricultural fields and potentially for quantifying the ability of the soil to resupply the soil solution with available $\mathrm{P}$ that could be used for crop uptake. Additionally, $\delta^{18} \mathrm{O}_{\mathrm{PO} 4}$ has broader implications for improving model structure and reducing uncertainty in model output, as current applications to simulate $\mathrm{P}$ fate and transport in tile drains are limited. Jensen et al. (2018), for instance, highlighted that stable isotopes of $\mathrm{C}$ and $\mathrm{N}$ have been effective at constraining uncertainty in water quality models by reducing the broad potential posterior solution space for highly parametric models and highlighting when perceived important processes disagree with isotope tracer values. An analogous process for simulating $\mathrm{P}$ pathways and fate is expected for the $\delta^{18} \mathrm{O}_{\mathrm{PO} 4}$ signature, given its sensitivity to pore-water residence time and vertical profile variability, which in turn has implications for improving field-scale nutrient management strategies.

Notwithstanding the significance of our findings, we also highlight some limitations of this study that may help inform experimental design of future field and watershed-scale $\delta^{18} \mathrm{O}_{\mathrm{PO} 4}$ studies. Namely, we highlight our assumptions regarding soil temperature and $\delta^{18} \mathrm{O}_{\mathrm{H} 2 \mathrm{O}}$. Our results indicate the importance of soil water extract $\mathrm{P}$ to, at least partly, equilibrate with $\delta^{18} \mathrm{O}_{\mathrm{H} 2 \mathrm{O}}$ during extended residence times in the vadose zone due to microbial activity. We generated a conservative range of potential equilibrium values, given that we did not measure either $\delta^{18} \mathrm{O}_{\mathrm{H} 2 \mathrm{O}}$ or temperature at our study site. Inclusion of these measurements in experimental designs over appropriate timescales in which equilibration could occur would allow more precise quantification of equilibrium and subsequently would reduce uncertainty in source and pathway partitioning. Further, our application was specific to one field site and one event, in which the field had a single P source. Future work should assess the efficacy of the tracer to provide insight for a range of soil test $\mathrm{P}$ levels, agronomic practices, and temporal domains.

\section{ACKNOWLEDGEMENTS}

The authors would like to thank the landowner of the study site, who provided access to the field and management data, and Jedediah Stinner, Katie Rumora, Marie Pollock, Phil Levison, and Sara Henderson for help in data collection and site maintenance. We greatly appreciate the edits and suggestions of the three anonymous reviewers, which greatly improved the quality of the manuscript. Funding for the edge-of-field research network was provided in part by several sources, including the 4R Research Fund (IPNI2014-USA-4RN09), U.S. EPA (DW-12-92342501-0), Ohio Farm Bureau, Conservation Innovation Grants (The Ohio State University, Grant No. 69-3A75-12-231; Heidelberg University, Grant No. 69-3A75-13-216), USDA-NRCS Mississippi River Basin Initiative, Nature Conservancy, Ohio Corn and Wheat Growers Association, Ohio Soybean Association, USDA-NRCS Cooperative Conservation Partnership Initiative, and USDA-NRCS Conservation Effects Assessment Project. This is Publication No. 17-05-101 of the Kentucky Agricultural Experiment Station and is published with the approval of the director. This work is supported by the USDA National Institute of Food and Agriculture.

\section{REFERENCES}

Abell, J. M., Özkundakci, D., Hamilton, D. P., \& Jones, J. R. (2012). Latitudinal variation in nutrient stoichiometry and chlorophyll-nutrient relationships in lakes: A global study. Fund. Appl. Limnol., 181(1), 1-14. https://doi.org/10.1127/18639135/2012/0272

Allen, R. G., Pereira, L. S., Raes, D., \& Smith, M. (1998). Crop evapotranspiration: Guidelines for computing crop water requirements. FAO Irrigation and Drainage Paper 56. Rome, Italy: United Nations FAO.

Baker, D. B., Johnson, L. T., Confesor, R. B., \& Crumrine, J. P. (2017). Vertical stratification of soil phosphorus as a concern for dissolved phosphorus runoff in the Lake Erie basin. J. Environ. Qual., 46(6), 1287-1295.

https://doi.org/10.2134/jeq2016.09.0337

Blann, K. L., Anderson, J. L., Sands, G. R., \& Vondracek, B. (2009). Effects of agricultural drainage on aquatic ecosystems: A review. Crit. Rev. Environ. Sci. Tech., 39(11), 909-1001. https://doi.org/10.1080/10643380801977966

Brauer, C. C., Teuling, A. J., Torfs, P. J. J. F., \& Uijlenhoet, R. (2014). The Wageningen Lowland Runoff Simulator (WALRUS): A lumped rainfall-runoff model for catchments with shallow groundwater. Geosci. Model Dev., 7(5), 23132332. https://doi.org/10.5194/gmd-7-2313-2014

Chang, S. J., \& Blake, R. E. (2015). Precise calibration of equilibrium oxygen isotope fractionations between dissolved phosphate and water from $3^{\circ} \mathrm{C}$ to $37^{\circ} \mathrm{C}$. Geochim. Cosmochim. Acta, 150, 314-329. https://doi.org/10.1016/j.gca.2014.10.030

Dahlke, H. E., Easton, Z. M., Lyon, S. W., Walter, M. T., Destouni, G., \& Steenhuis, T. S. (2012). Dissecting the variable source area concept: Subsurface flow pathways and water mixing processes in a hillslope. J. Hydrol., 420-421, 125-141. https://doi.org/10.1016/j.jhydrol.2011.11.052

Duncan, E. W., King, K. W., Williams, M. R., LaBarge, G., Pease, L. A., Smith, D. R., \& Fausey, N. R. (2017). Linking soil phosphorus to dissolved phosphorus losses in the Midwest. Agric. Environ. Lett., 2(1). https://doi.org/10.2134/ael2017.02.0004

Dutton, A., Wilkinson, B. H., Welker, J. M., Bowen, G. J., \& Lohmann, K. C. (2005). Spatial distribution and seasonal variation in ${ }^{18} \mathrm{O} /{ }^{16} \mathrm{O}$ of modern precipitation and river water across the conterminous USA. Hydrol. Proc., 19(20), 41214146. https://doi.org/10.1002/hyp.5876

Elsbury, K. E., Paytan, A., Ostrom, N. E., Kendall, C., Young, M. B., McLaughlin, K., ... Watson, S. (2009). Using oxygen isotopes of phosphate to trace phosphorus sources and cycling in Lake Erie. Environ. Sci. Tech., 43(9), 3108-3114. https://doi.org/10.1021/es8034126

Fernandez, G. P., Chescheir, G. M., Skaggs, R. W., \& Amatya, D. M. (2005). Development and testing of watershed-scale models for poorly drained soils. Trans. ASAE, 48(2), 639-652. https://doi.org/10.13031/2013.18323

Ford, W. I., King, K. W., Williams, M. R., \& Confesor, R. B. (2017). Modified APEX model for simulating macropore phosphorus contributions to tile drains. J. Environ. Qual., 46(6), 1413-1423. https://doi.org/10.2134/jeq2016.06.0218

Gooddy, D. C., Lapworth, D. J., Bennett, S. A., Heaton, T. H. E., Williams, P. J., \& Surridge, B. W. J. (2016). A multi-stable isotope framework to understand eutrophication in aquatic ecosystems. Water Res., 88, 623-633. https://doi.org/10.1016/j.watres.2015.10.046

Granger, S. J., Bol, R., Meier-Augenstein, W., Leng, M. J., Kemp, H. F., Heaton, T. H. E., \& White, S. M. (2010). The hydrological response of heavy clay grassland soils to rainfall in southwest England using $\delta^{2} \mathrm{H}$. Rapid Comm. Mass Spectrom., 24(5), 475-482. https://doi.org/10.1002/rcm.4281 
Granger, S. J., Heaton, T. H. E,, Pfahler, V., Blackwell, M. S. A., Yuan, H., \& Collins, A. L. (2017). The oxygen isotopic composition of phosphate in river water and its potential sources in the Upper River Taw catchment, UK. Sci. Total Environ., 574, 680-690. https://doi.org/10.1016/j.scitotenv.2016.09.007

Gross, A., Turner, B. L., Wright, S. J., Tanner, E. V. J., Reichstein, M., Weiner, T., \& Angert, A. (2015). Oxygen isotope ratios of plant-available phosphate in lowland tropical forest soils. Soil Biol. Biochem., 88, 354-361. https://doi.org/10.1016/j.soilbio.2015.06.015

Huffman, R. L., Fangmeier, D. D., Elliot, W. J., \& Workman, S. R. (2012). Soil and water conservation engineering (7th ed.). St. Joseph, MI: ASABE.

Jaisi, D. P., Kukkadapu, R. K., Stout, L. M., Varga, T., \& Blake, R. E. (2011). Biotic and abiotic pathways of phosphorus cycling in minerals and sediments: Insights from oxygen isotope ratios in phosphate. Environ. Sci. Tech., 45(15), 6254-6261. https://doi.org/10.1021/es200456e

Jarvie, H. P., Johnson, L. T., Sharpley, A. N., Smith, D. R., Baker, D. B., Bruulsema, T. W., \& Confesor, R. (2017). Increased soluble phosphorus loads to Lake Erie: Unintended consequences of conservation practices? J. Environ. Qual., 46(1), 123-132. https://doi.org/10.2134/jeq2016.07.0248

Jensen, A., Ford, W., Fox, J., \& Husic, A. (2018). Improving instream nutrient routines in water quality models using stable isotope tracers: A review and synthesis. Trans. ASABE, 61(1), 139-157. https://doi.org/10.13031/trans. 12545

Joshi, S. R., Li, X., \& Jaisi, D. P. (2016). Transformation of phosphorus pools in an agricultural soil: An application of oxygen-18 labeling in phosphate. SSSA J., 80(1), 69-78. https://doi.org/10.2136/sssaj2015.06.0219

Kendall, C., \& Coplen, T. B. (2001). Distribution of oxygen-18 and deuterium in river waters across the United States. Hydrol. Proc., 15(7), 1363-1393. https://doi.org/10.1002/hyp.217

Kennedy, C. D., Bataille, C., Liu, Z., Ale, S., VanDeVelde, J., Roswell, C. R., ... Bowen, G. J. (2012). Dynamics of nitrate and chloride during storm events in agricultural catchments with different subsurface drainage intensity (Indiana, USA). $J$. Hydrol., 466-467, 1-10. https://doi.org/10.1016/j.jhydrol.2012.05.002

King, K. W., Williams, M. R., \& Fausey, N. R. (2015a). Contributions of systematic tile drainage to watershed-scale phosphorus transport. J. Environ. Qual., 44(2), 486-494. https://doi.org/10.2134/jeq2014.04.0149

King, K. W., Williams, M. R., Dick, W. A., \& LaBarge, G. A. (2016). Decreasing phosphorus loss in tile-drained landscapes using flue gas desulfurization gypsum. J. Environ. Qual., 45(5), 1722-1730. https://doi.org/10.2134/jeq2016.04.0132

King, K. W., Williams, M. R., Macrae, M. L., Fausey, N. R., Frankenberger, J., Smith, D. R., ... Brown, L. C. (2015b). Phosphorus transport in agricultural subsurface drainage: A review. J. Environ. Qual., 44(2), 467-485. https://doi.org/10.2134/jeq2014.04.0163

Klaus, J., Zehe, E., Elsner, M., Kulls, C., \& McDonnell, J. J. (2013). Macropore flow of old water revisited: Experimental insights from a tile-drained hillslope. Hydrol. Earth Syst. Sci., 17(1), 103-118. https://doi.org/10.5194/hess-17-103-2013

Klaus, J., Zehe, E., Elsner, M., Palm, J., Schneider, D., Schroder, B., ... West, S. (2014). Controls of event-based pesticide leaching in natural soils: A systematic study based on replicated field-scale irrigation experiments. J. Hydrol., 512, 528-539. https://doi.org/10.1016/j.jhydrol.2014.03.020

Macrae, M. L., English, M. C., Schiff, S. L., \& Stone, M. (2007). Intra-annual variability in the contribution of tile drains to basin discharge and phosphorus export in a first-order agricultural catchment. Agric. Water Mgmt., 92(3), 171-182. https://doi.org/10.1016/j.agwat.2007.05.015

McLaughlin, K., Silva, S., Kendall, C., Stuart-Williams, H., \& Paytan, A. (2004). A precise method for the analysis of $\delta^{18} \mathrm{O}$ of dissolved inorganic phosphate in seawater. Limnol. Oceanogr. Methods, 2(7), 202-212. https://doi.org/10.4319/lom.2004.2.202

McLaughlin, K., Young, M. B., Paytan, A., \& Kendall, C. (2013). The oxygen isotopic composition of phosphate: A tracer for phosphate sources and cycling. In Application of isotope techniques for assessing nutrient dynamics in river basins (pp. 93-110). IAEA-TECDOC-1695. Vienna, Austria: International Atomic Energy Agency.

Mirus, B. B., \& Nimmo, J. R. (2013). Balancing practicality and hydrologic realism: A parsimonious approach for simulating rapid groundwater recharge via unsaturated-zone preferential flow. Water Resour. Res., 49(3), 1458-1465. https://doi.org/10.1002/wrcr.20141

Moriasi, D. N., Arnold, J. G., Van Liew, M. W., Bingner, R. L., Harmel, R. D., \& Veith, T. L. (2007). Model evaluation guidelines for systematic quantification of accuracy in watershed simulations. Trans. ASABE, 50(3), 885-900. https://doi.org/10.13031/2013.23153

Nimmo, J. R. (2012). Preferential flow occurs in unsaturated conditions. Hydrol. Proc., 26(5), 786-789. https://doi.org/10.1002/hyp.8380

Pease, L. A., King, K. W., Williams, M. R., LaBarge, G. A., Duncan, E. W., \& Fausey, N. R. (2018). Phosphorus export from artificially drained fields across the eastern Corn Belt. J. Great Lakes Res., 44(1), 43-53. https://doi.org/10.1016/j.jglr.2017.11.009

Pistocchi, C., Tamburini, F., Gruau, G., Ferhi, A., Trevisan, D., \& Dorioz, J.-M. (2017). Tracing the sources and cycling of phosphorus in river sediments using oxygen isotopes: Methodological adaptations and first results from a case study in France. Water Res., 111, 346-356. https://doi.org/10.1016/j.watres.2016.12.038

Pote, D. H., Daniel, T. C., Moore Jr., P. A., Nichols, D. J., Sharpley, A. N., \& Edwards, D. R. (1996). Relating extractable soil phosphorus to phosphorus losses in runoff. SSSA J., 60(3), 855859. https://doi.org/10.2136/sssaj1996.03615995006000030025x

Powers, S. M., Bruulsema, T. W., Burt, T. P., Chan, N. I., Elser, J. J., Haygarth, P. M., ... Zhang, F. (2016). Long-term accumulation and transport of anthropogenic phosphorus in three river basins. Nat. Geosci., 9, 353-356. https://doi.org/10.1038/ngeo2693

Rupp, H., Meissner, R., \& Leinweber, P. (2004). Effects of extensive land use and re-wetting on diffuse phosphorus pollution in fen areas: Results from a case study in the Dromling catchment, Germany. J. Plant Nutr. Soil Sci., 167(4), 408-416. https://doi.org/10.1002/jpln.200421395

Self-Davis, M. L., Moore Jr., P. A., \& Joern, B. C. (2000). Determination of water- and/or dilute salt-extractable phosphorus. Southern Cooperative Series Bulletin No. 396. Raleight, NC: North Carolina State University.

Tamburini, F., Bernasconi, S. M., Angert, A., Weiner, T., \& Frossard, E. (2010). A method for the analysis of the $\delta^{18} \mathrm{O}$ of inorganic phosphate extracted from soils with $\mathrm{HCl}$. European $J$. Soil Sci., 61(6), 1025-1032. https://doi.org/10.1111/j.13652389.2010.01290.x

Tamburini, F., Pfahler, V., Bunemann, E. K., Guelland, K., Bernasconi, S. M., \& Frossard, E. (2012). Oxygen isotopes unravel the role of microorganisms in phosphate cycling in soils. Environ. Sci. Tech., 46(11), 5956-5962. https://doi.org/10.1021/es300311h

Tamburini, F., Pfahler, V., von Sperber, C., Frossard, E., \& Bernasconi, S. M. (2014). Oxygen isotopes for unraveling 
phosphorus transformations in the soil-plant system: A review. SSSA J., 78(1), 38-46. https://doi.org/10.2136/sssaj2013.05.0186dgs

Tonderski, K., Andersson, L., Lindstrom, G., St Cyr, R., Schonberg, R., \& Taubald, H. (2017). Assessing the use of $\delta^{18} \mathrm{O}$ in phosphate as a tracer for catchment phosphorus sources. Sci. Total Environ., 607-608, 1-10. https://doi.org/10.1016/j.scitotenv.2017.06.167

USDA-NRCS. (1997). National engineering handbook, Irrigation guide Part 652, Ch. 3 crops. Washington, DC: USDA Natural Resources Conservation Service.

USEPA. (1983). Methods for chemical analysis of water and wastes. EPA 600/4-79-020. Cincinnati, OH: U.S. Environmental Protection Agency.

Vidon, P., \& Cuadra, P. E. (2010). Impact of precipitation characteristics on soil hydrology in tile-drained landscapes. Hydrol. Proc., 24(13), 1821-1833. https://doi.org/10.1002/hyp.7627

Vitosh, M. L., Johnson, J. W., \& Mengel, D. B. (1995). Tri-state fertilizer recommendations for corn, soybeans, wheat, and alfalfa. Bulletin E-2567. West Lafayette, IN: Purdue University Extension. Retrieved from https://extension.purdue.edu/extmedia/AY/AY-9-32.pdf

Weiler, M., \& Naef, F. (2003). An experimental tracer study of the role of macropores in infiltration in grassland soils. Hydrol. Proc., 17(2), 477-493. https://doi.org/10.1002/hyp.1136

Williams, J. R., Izaurralde, R. C., \& Steglich, E. M. (2012). Agricultural Policy/Environmental eXtender model: Theoretical documentation. Temple, TX: Blackland Research and Extension Center.
Williams, M. R., King, K. W., Ford, W., \& Fausey, N. R. (2016b). Edge-of-field research to quantify the impacts of agricultural practices on water quality in Ohio. J. Soil Water Cons., 71(1), 9A-12A. https://doi.org/10.2489/jswc.71.1.9A

Williams, M. R., King, K. W., Ford, W., Buda, A. R., \& Kennedy, C. D. (2016a). Effect of tillage on macropore flow and phosphorus transport to tile drains. Water Resour. Res., 52(4), 2868-2882. https://doi.org/10.1002/2015WR017650

Young, M. B., McLaughlin, K., Kendall, C., Stringfellow, W., Rollog, M., Elsbury, K., ... Paytan, A. (2009). Characterizing the oxygen isotopic composition of phosphate sources to aquatic ecosystems. Environ. Sci. Tech., 43(14), 5190-5196. https://doi.org/10.1021/es900337q

Zambrano-Bigiarini, M., \& Rojas, R. (2013). A model-independent particle swarm optimisation software for model calibration. Environ. Model. Software, 43, 5-25. https://doi.org/10.1016/j.envsoft.2013.01.004

Zhang, T. Q., Tan, C. S., Zheng, Z. M., Welacky, T., \& Wang, Y. T. (2017). Drainage water management combined with cover crop enhances reduction of soil phosphorus loss. Sci. Total Environ., 586, 362-371. https://doi.org/10.1016/j.scitotenv.2017.02.025

Zohar, I., Shaviv, A., Young, M., Kendall, C., Silva, S., \& Paytan, A. (2010a). Phosphorus dynamics in soils irrigated with reclaimed waste water or fresh water: A study using oxygen isotopic composition of phosphate. Geoderma, 159(1), 109-121. https://doi.org/10.1016/j.geoderma.2010.07.002

Zohar, I., Shaviv, A., Klass, T., Roberts, K., \& Paytan, A. (2010b). Method for the analysis of oxygen isotopic composition of soil phosphate fractions. Environ. Sci. Tech., 44(19), 7583-7588. https://doi.org/10.1021/es100707f 